\title{
Angiotensin II Enhances Proliferation and Inflammation through AT1/PKC/NF- kB Signaling Pathway in Hepatocellular Carcinoma Cells
}

\author{
Yuanyuan Jia Zhidong Wang ${ }^{\mathrm{b}}$ Zongfang Lic Aijun Zhang ${ }^{\mathrm{d}}$ Yaofeng Jine \\ Haiyan Chen ${ }^{a}$ Xiaofeng Le ${ }^{f}$ \\ aScientific Research Center, ${ }^{b}$ Geriatric digestive surgery, ${ }^{\mathrm{C}}$ National Local Joint Engineering Research \\ Center of Biodiagnostics and Biotherapy, dDepartmant of Pharmacy, e Departmant of Pathology, \\ The Second Affiliated Hospital, Xi'an Jiaotong University, Xi'an, China; ${ }^{\dagger}$ Department of Experimental \\ Therapeutics, The University of Texas M.D. Anderson Cancer Center, Texas, USA
}

\section{Key Words}

Angiotensin II • Hepatocellular carcinoma $•$ Proliferation $•$ Inflammation $\bullet$ PKC $・ N F-\kappa B$

\begin{abstract}
Background/Aims: The pathogenesis of hepatocellular carcinoma (HCC) is mainly characterized by persistent cycles of liver injury, inflammation, and compensatory hepatocyte proliferation. Angiotensin II (Ang II) behaves as an endogenous pro-inflammatory molecule playing a significant role in HCC, however, the molecular link between Ang II, proliferation and inflammation remains unclear. Methods: Human HCC cell lines (HepG-2, SMMC-7721, MHCC97-H) were incubated with Ang II at the indicated concentrations for $24,48,72 \mathrm{~h}$. MTT, BrdU ELISA, plate colony formation assay, immunohistochemistry, ELISA, small-interfering RNA(siRNA) transfection, quantitative real-time PCR and western blot were applied to assess their functional, morphological and molecular mechanisms in HCC cell lines. Results: High expression of Ang II type 1 receptor (AT1) and low expression of AT2 in HCC cells and tissues were found. Next, Ang II could significantly enhance cell growth and proliferation. Albeit Ang II slightly increased the percentage of HCC cells in the G0/G1 phase using flow cytometry analysis, no statistically significant alterations were shown. Further studies suggested that Ang II could directly induce proliferation associated proteins C-myc and proliferating cell nuclear antigen (PCNA) expressions, and inflammatory cytokines tumor necrosis factor-alpha (TNF- $\alpha$ ) and C-reactive protein (CRP) productions in HCC cells. Interestingly, blocking AT1 and AT1 siRNA evidently inhibited Ang II-induced cell proliferation and inflammatory responses in HCC cells. More importantly, these effects may be mediated by AT1/PKC/NF- $\kappa B$ signaling pathway in HCC cell lines. Conclusions: The results propose that Ang II/AT1/PKC/NF-KB signaling pathway is necessary for proliferation and inflammation of HCC cells, which increases our understanding of the pathogenesis and provides clues for developing new strategies against Ang II-related progress of HCC.




\section{Cellular Physiology Cell Physiol Biochem 2016;39:13-32

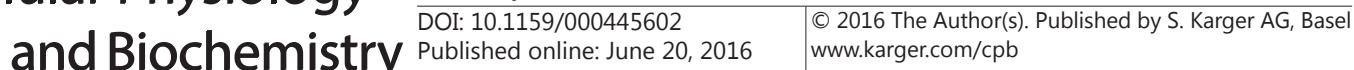 \\ Ji et al.: Angiotensin II Enhances Proliferation and Inflammation via AT1/ PKC/NF-кB}

\section{Introduction}

Hepatocellular carcinoma (HCC), the major form of primary liver cancer, is one of the most common human cancers and the third leading cause of cancer-related mortality worldwide [1]. The pathogenesis of HCC is frequently linked with continuous hepatocyte death, inflammatory cell infiltration and compensatory liver regeneration [2]. The development of HCC is regulated by various oncogenes and signalling pathways [3]. Although the etiology of human HCC is well established, its molecular pathogenesis is poorly understood. As a consequence, it is important to understand the molecular characteristics and related biological mechanisms in the proliferation, migration, metastasis and inflammation of HCC for the development of earlier screening markers and therapeutic targets [4].

Recent studies have revealed that renin-angiotensin system (RAS) is involved in many types of cancer including HCC. Angiotensin II (Ang II), a multifunctional bioactive peptide of RAS, plays a fundamental role in cancer cell lines. Several studies have proven that suppression of Ang II by a clinically used angiotensin-converting enzyme inhibitor (ACEI) significantly attenuated the cell growth and hepatocarcinogenesis [5]. Our previous study has demonstrated that Ang II induces angiogenic factors production partly via AT1/JAK2/ STAT3/SOCS3 signaling pathway in MHCC97H cells, which is involved in the metastasis and progress of HCC [6]. Moreover, it has been reported that Ang II induces contraction and proliferation of hepatic stellate cells [7]. It is well known that Ang II is associated with vascular proliferation in tumor and non-tumor models via its receptors Ang II type 1 (AT1) or type 2 receptors (AT2) [8].

The role of inflammation in tumor progression or metastasis has been extensively described. Indeed, inflammation plays important roles in hepatocarcinogenesis. Ang II stimulates the release of pro-inflammatory cytokines, and it functions as an inflammatory molecule [9]. Ang II receptor antagonists block inflammatory signaling both in cancer cells and in normal cells. Furthermore, they are also effective in the treatment of cancer by inhibiting tumor progression, vascularization and metastasis [10]. The activation of AT1 pro-inflammatory effect, further promotes the expression of many pro-inflammatory mediators, such as cytokines, chemokines and adhesion molecules through the activation of signaling pathway $[11,12]$. Accumulating evidence has indicated that inflammation is closely related to liver cancer [13]. Inflammatory cytokines such as tumor necrosis factoralpha (TNF- $\alpha$ ) and C-reactive protein (CRP) facilitate cancer growth, invasion, metastasis and angiogenesis, which predisposes to the development of HCC $[14,15]$. Apart from the attention Ang II has attracted in relation to its roles in the cardiovascular disease and renal injury [16-18], another function of Ang II related to cell proliferation and inflammation has recently been focused on, especially in the prevention and treatment of HCC. Therefore, the underlying molecular mechanism of Ang II-induced cell proliferation and inflammation in HCC cells needs to be elucidated.

Herein we demonstrated that Ang II showed the ability to induce cell growth and proliferation in HCC cell lines (HepG-2, SMMC-7721, MHCC97-H). In addition, Ang II elicited productions of inflammatory cytokines TNF- $\alpha$ and CRP in HCC cell lines. More importantly, these effects might be mediated by AT1/PKC/NF- $\kappa \mathrm{B}$ signaling pathway in HCC cell lines.

\section{Materials and Methods}

Reagents

Dulbecco's modified Eagle's medium (DMEM) and fetal bovine serum (FBS) were purchased from Gibco BRL (Carlsbad, CA, USA). Ang II, PD123319, PDTC and methylthiazoletetrazolium (MTT) were provided by Sigma (St. Louis, MO, USA). Losartan was produced by Merk (Darmstadt, Germany). Polyclonal anti-human C-myc, proliferating cell nuclear antigen (PCNA), TNF- $\alpha$, CRP, AT1, AT2 and anti- $\beta$-smooth muscle actin antibodies were supplied by ABCAM (Cambridge, UK). Polyclonal anti-human AT1, AT2, PKC and NF- $\kappa$ B antibodies were obtained from Santa Cruz Biotechnology (Santa Cruz, CA, USA). Phospho-NFкB p65 (Ser536) antibody was obtained from Cell Signaling Technology (Danvers, MA, USA). Propidium 


\section{Cellular Physiology Cell Physiol Biochem 2016;39:13-32 and Biochemistry Published online: June 20,2016 $\quad \begin{aligned} & \text { DOI: 10.1159/000445602 } 2016 \text { The Author(s). Published by S. Karger AG, Basel } \\ & \text { www.karger.com/cpb }\end{aligned}$ \\ Ji et al.: Angiotensin II Enhances Proliferation and Inflammation via AT1/ PKC/NF-кB}

iodide (PI) was purchased by Dingguo Changsheng Bioengineering Institute (Beijing, China).Human TNF- $\alpha$ and CRP ELISA kits were obtained from Invitrogen (Carlsbad, CA, USA). Brdu-ELISA kit was provided by Maiyueer Bioengineering Institute (Shanghai, China). A dual luciferase reporter gene assay kit to assay NFKB activity was purchased from Promega (Madison, WI, USA). Small-interfering RNA (siRNA) specific for AT1 (siGENOME SMARTpool, M-005428-02-0005) and negative control siRNA (siGENOME Non-Targeting siRNA Pool, D-001206-13-05) and DharmaFECT 4 transfection reagent (T-2002-04) were purchased from Dharmacon (Lafayette, CO, USA).

\section{Cell culture}

Human MHCC97H cell, a typical HCC cell line with high metastatic potential [19], was obtained from Liver Cancer Institute of Fudan University (Shanghai, China). HepG-2 and SMMC-7721 cell lines were obtained from the American Type Culture Collection (ATCC).These cell lines were authenticated by STR DNA analysis (Genetica DNA Laboratories) and were found to be mycoplasma-free (Lonza, USA). All cell lines were cultured with DMEM supplemented with $10 \% \mathrm{FBS}$ and antibiotics at $37^{\circ} \mathrm{C}$ in a $5 \% \mathrm{CO}_{2}$-humidified atmosphere.

\section{MTT assay}

Human HCC cell lines (HepG-2, SMMC-7721, MHCC97-H) were seeded into 96-well plates at a density of $2 \times 10^{4}$ cells per well, and incubated with Ang II at the indicated concentrations for $24,48,72 \mathrm{~h}$. The cell viability was analyzed by MTT assay. At the indicated time points, $20 \mu \mathrm{l}$ of MTT solution $(5 \mathrm{mg} / \mathrm{ml})$ was added to each well and incubated at $37^{\circ} \mathrm{C}$ for $4 \mathrm{~h}$. Then, the medium was replaced with $150 \mu \mathrm{l}$ of dimethyl sulfoxide. The absorbance of each well was measured in an enzyme immunoassay analyzer at $490 \mathrm{~nm}$. The experiment was performed at least three times independently.

\section{BrdU ELISA assay}

The proliferation was performed as described previously [20]. In brief, equal number of HepG2, SMMC-7721 and MHCC97-H cells were plated in 96-well plates and serum-starved overnight. Serum starvation induced cell-cycle synchronization so that most of the cells stay in the G1/S transition just before the S phase entry. Human HCC cell lines were seeded into 96-well plates at $1 \times 10^{4}$ cells per well, and incubated with Ang II at the indicated concentrations for 24, 48, $72 \mathrm{~h}$. Cells were treated with BrdU labeling for $2 \mathrm{~h}$, then poured the marking liquid, incubated at $60^{\circ} \mathrm{C}$ for $1 \mathrm{~h} .200 \mu \mathrm{l} \mathrm{FixDenat} \mathrm{was} \mathrm{added,} \mathrm{and} \mathrm{incubated}$ at room temperature for $30 \mathrm{~min}$. After $100 \mu \mathrm{l}$ Brdu-POD solution was added, incubated at room temperature for $90 \mathrm{~min}$, and $100 \mu \mathrm{l}$ substrate solution was added, and incubated at room temperature for $30 \mathrm{~min}$. The result was quantified by measuring the absorbance of $370 \mathrm{~nm}$. The experiment was performed at least three times independently.

\section{Plate colony formation assay}

Human HCC cell lines (HepG-2, SMMC-7721, MHCC97-H) were seeded into 6-well plates at a density of 200 cells per well. After 10 days, cells incubated with Ang II at the indicated concentrations for $48 \mathrm{~h}$. Then cells were washed with PBS, fixed in 10\% methanol for $15 \mathrm{~min}$, and stained with crystal violet for $10 \mathrm{~min}$. Visualized colonies were then photographed and scored. The experiment was repeated at least three times.

\section{Cell cycle analysis}

Human HCC cell lines (HepG-2, SMMC-7721, MHCC97-H) were trypsinized and washed in PBS. Cells were then resuspended in cold PBS: ethanol $(1: 1, \mathrm{v} / \mathrm{v})$ and incubated for $1 \mathrm{~h}$ on ice. After incubation, cells were centrifuged at $1000 \mathrm{~g}$ for $5 \mathrm{~min}$ at $4^{\circ} \mathrm{C}$. Cells were rehydrated and washed twice with PBS before being stained by incubation with $50 \mu \mathrm{g} / \mathrm{ml} \mathrm{PI}$ and $500 \mu \mathrm{g} / \mathrm{ml} \mathrm{RNase} \mathrm{A} \mathrm{for} 30 \mathrm{~min}$ in the dark at room temperature. Cells were then run on a FACS Calibur Flow Cytometer (Becton Dickenson, CA, USA) and the percentage of cells in $\mathrm{G}_{0}-\mathrm{G}_{1}, \mathrm{~S}$ and $\mathrm{G}_{2}-\mathrm{M}$ arrest were calculated. The experiment was repeated at least three times.

\section{Confocal microscopy}

Human HCC cell lines (HepG-2, SMMC-7721, MHCC97-H) were inoculated on cover slips and grown to confluence, and treated with Ang II at the indicated concentrations for $48 \mathrm{~h}$. After the treatment, as described previously [6], the cells were fixed with $4 \%$ formaldehyde-PBS for $15 \mathrm{~min}$. The cell membranes 


\section{Cellular Physiology Cell Physiol Biochem 2016;39:13-32

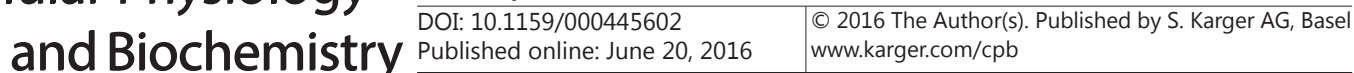 \\ Ji et al.: Angiotensin II Enhances Proliferation and Inflammation via AT1/ PKC/NF- $\mathrm{KB}$}

were fenestrated with $0.3 \%$ Triton-100-PBS, and nonspecific binding sites were blocked with $10 \%$ goat serum. The cells were incubated with rabbit anti-human antibody C-myc (1:250) and then incubated with the secondary antibody conjugated to fluorescein isothiocyanate (FITC)(1: 400). Immunofluorescence imaging was captured in a Leica TCS SP8 laser confocal scanning microscope (Germany), and fluorescent intensity of C-myc was detected. Data were expressed as relative to control (\%).The experiment was performed at least three times independently.

ELISA

Human HCC cell lines (HepG-2, SMMC-7721, MHCC97-H) were seeded into 6-well plates at a density of $5 \times 10^{5}$ cells/well, and then incubated with Ang II at the indicated concentrations for the indicated time. In another experiment, the cells were pretreated with AT1 inhibitor losartan $(1 \mu \mathrm{M})$ and AT2 inhibitor PD123319 $(10 \mu \mathrm{M})$ for $1 \mathrm{~h}$ and stimulated with Ang II (100 $\mathrm{nM})$ for $48 \mathrm{~h}$. Furthermore, after application of NF- $\kappa$ B inhibitor PDTC $(100 \mu \mathrm{M})$ for $1 \mathrm{~h}$, cells were stimulated with Ang II (100 nM) for $48 \mathrm{~h}$. TNF- $\alpha$ and CRP levels in the supernatant were measured with ELISA kits according to the manufacturer's instructions. Each assay was done in triplicate.

\section{Small-interfering RNA transfection}

As described previously [6]. Cells $\left(1 \times 10^{5}\right)$ were seeded into 6-well plates and were grown until $60 \%-80 \%$ confluent. The cells were transiently transfected with $50 \mathrm{nM}$ of AT1 small-interfering RNA (siRNA) or negative control siRNA (NC siRNA) using DharmaFECT 4 transfection reagents according to the manufacturer's instructions. AT1 siRNA sequence were: sense 5'-AUACGUGACUGUAGAAUUG-3', antisense 5'-CAAUUCUACAGUCACGUAU-3'; NC siRNA sequence were: sense 5'-UAGCGACUAAACACAUCAA-3', antisense 5'-UAAGGCUAUGAAGAGAUAC-3'. After $48 \mathrm{~h}$, protein expression and mRNA levels of AT1 were detected by western blot, quantitative real time-PCR and RT-PCR. Transfection rates of $60 \%-70 \%$ of the cells were accepted for all the experiments.

\section{$N F-\kappa B$ luciferase reporter assay}

$\mathrm{NF}-\kappa \mathrm{B}$ luciferase reporter assays were performed as described previously [21]. Briefly, cells were co-transfected with a NF- $\kappa B$-luc reporter construct and a renilla luciferase-expressing plasmid (internal control to normalize for transfection efficiency) using Lipofectamine 2000 according to the manufacturer's instructions. After treatment for $48 \mathrm{~h}$, firefly and renilla luciferase activities were tested using a dual luciferase reporter gene assay kit. NF- $\mathrm{BB}$ transcriptional activity = (relative light units of firefly luciferase) relative light units of renilla luciferase $\times 100$. Each assay was done in triplicate.

\section{Quantitative real-time PCR and RT-PCR}

mRNA levels were determined by our previous method [22]. Total RNA was isolated using a TRIzol Kit (Invitrogen Corp., Carlsbad, CA, USA). cDNA was synthesized from $1 \mu \mathrm{g}$ samples of total RNA using PrimeScript ${ }^{\mathrm{TM}}$ RT Master Mix Kit (Takara, Japan) following the manufacturer's instructions. Real-time polymerase chain reaction (PCR) was performed with the SYBR Premix Ex Taq ${ }^{\mathrm{TM}}$ II Perfect Real Time kit (Takara, Japan) on an ABI QPCR System (Applied Biosystems, CA, USA) following the manufacturer's instructions. The samples were run in triplicate. Primers for human C-myc, PCNA, TNF- $\alpha$, CRP and $\beta$-actin were designed with Beacon designer v 4.0 (Premier Biosoft, USA) (see Table 1 for the sequences). Traditional PCR was performed according to the manufacturer's instructions. The RT-PCR products were analyzed by electrophoresis through $2 \%$ agarose gels containing ethidium bromide. A melting point dissociation curve generated by the instrument was used to confirm that only a single product was present. Quantization of relative gene expression was calculated by the comparative Ct method $\left(2^{-\Delta \Delta \mathrm{CT}}\right)$ as described by the manufacturer. Data were normalized to human $\beta$-actin mRNA levels. Three independent experiments were carried out to study mRNA levels.

\section{Western blot}

As described previously [6], protein samples (25 $\mu \mathrm{g}$ ) were separated on sodium dodecyl sulfate polyacrylamide gel electrophoresis gels and transferred onto a polyvinylidene difluoride membrane (BioRad Laboratories, Hercules, CA, United States). The membranes were blocked with 5\% nonfat dry milk in Tris-buffered saline containing $0.1 \%$ Tween 20 , and incubated with specific antibodies against C-myc 


\section{Cellular Physiology Cell Physiol Biochem 2016;39:13-32 and Biochemistry Published online: June 20, $2016 \quad \begin{aligned} & \text { DOI: 10.1159/000445602 } 2016 \text { The Author(s). Published by S. Karger AG, Basel } \\ & \text { www.karger.com/cpb }\end{aligned}$ \\ Ji et al.: Angiotensin II Enhances Proliferation and Inflammation via AT1/ PKC/NF- $\mathrm{BB}$}

Table 1. Primers used for real-time PCR analysis

\begin{tabular}{|c|c|c|c|}
\hline Gene & Primer sequence & Accession number & Expected size (bp) \\
\hline C-myc & $\begin{array}{l}\text { 5'-GCAGCTGCTTAGACGCTGGA-3', } \\
5^{\prime} \text { - CGCAGTAGAAATACGGCTGCAC-3' }\end{array}$ & NM_002467.4 & 136 \\
\hline PCNA & $\begin{array}{l}\text { 5'-CGGATGGA AATGGACAACGACA-3', } \\
5^{\prime} \text {-CGCTTAGCGAGATAGCCTGAC- } 3^{\prime}\end{array}$ & NM_182649.1 & 172 \\
\hline TNF- $\alpha$ & $\begin{array}{l}\text { 5'-GCTTAGTGACATCCCGATTCTTC-3', } \\
\text { 5'-CATTCTGCCTTGAACTCGTGTGAA-3' }\end{array}$ & NM_000594.3 & 146 \\
\hline CRP & $\begin{array}{l}\text { 5'- CATGTAGCAGCGATGGGA-3', } \\
5^{\prime} \text { - CACTGTCATACCGCCACTGA-3' }\end{array}$ & NM_000567.2 & 155 \\
\hline$\beta$-actin & $\begin{array}{l}\text { 5'- TGGCACCCAGCACAATGAA-3', } \\
\text { 5'- CTAAGTCATAGTCCGCCTAGAAGCA-3' }\end{array}$ & NM_001101.3 & 186 \\
\hline
\end{tabular}

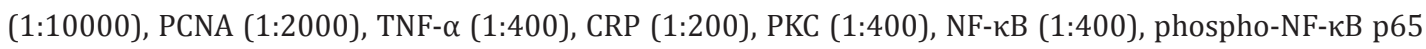
$(1: 400)$ and $\beta$-actin (1:1000). The expression of $\beta$-actin was used as a loading control. Reagents (Pierce Corp., Rockford, IL, United States) for the enhanced chemiluminescence were applied to the blots, and the light signals were detected by X-ray film. Optical densities of the bands were scanned and quantified with the Syngene Gene Tools (Syngene Corp., Cambridge, United Kingdom). Three independent experiments were carried out to study protein expression.

Immunohistochemistry (IHC) of liver cancer tissues

Specimens of HCC tissues were obtained from 62 HCC patients who underwent hepatic resection at the Second Affiliated Hospital of Xi'an Jiaotong University from January 2010 to January 2016. 8 nonmalignant liver tissue samples from patients who underwent biopsy were utilized. And all of the specimens were subjected to IHC. Prior informed consent was obtained and the study protocol was approved by the Ethics Committee of the Second Affiliated Hospital of Xi'an Jiaotong University. Tissue samples were fixed in $10 \%$ formalin for $48 \mathrm{~h}$ and embedded with paraffin. $5 \mu \mathrm{m}$ sections were deparaffinized followed by antigen retrieval using citric acid buffer ( $\mathrm{pH} 6.0,95^{\circ} \mathrm{C}$ for $20 \mathrm{~min}$ ). Slides were treated with $3 \%$ hydrogen peroxide to block endogenous peroxidase activity. After $20 \mathrm{~min}$ of blocking in $1 \%$ bovine serum albumin (BSA), the slides were incubated overnight at $4{ }^{\circ} \mathrm{C}$ with rabbit anti-human AT1 (1:50) and AT2 (1:50) antibodies. Next, the slides were incubated with $2 \mu \mathrm{g} / \mathrm{ml}$ of biotinylated anti-rabbit IgG secondary antibody for $40 \mathrm{~min}$ at room temperature. Subsequently, the sections were stained using Standard Ultra-Sensitive ABC Peroxidase Staining kit (Pierce of Thermo Fisher Scientific) and 3,3'-diaminobenzidine, and counterstained by hematoxylin. The bright field images were captured with ZEISS Axio Scan Z1 (Germany). The immunostaining results were independently observed and interpreted by two pathologists unaware of clinical data.

Statistical analysis

All data are expressed as mean \pm SEM. Student's $t$ test or one- or two-way ANOVA test was used to determine the significance among groups. A value of $p<0.05$ was considered to be statistically significant.

\section{Results}

Expressions of Ang II receptors (AT1 and AT2) in HCC

The presence of AT1 and AT2 in human HCC cell lines (HepG-2, SMMC-7721, MHCC97-H) was detected by RT-PCR and western blot. AT1 mRNA and protein expressions were obviously enhanced (Fig. 1A), however, AT2 mRNA and protein expressions were minimally detectable in HCC cell lines (Fig. 1B). Furthermore, human non-cancerous liver tissues and liver cancer tissues with staining to immunohistochemical analysis for AT1 and AT2 were performed. Non-cancerous liver tissues used as controls showed decreased AT1 or AT2 expression, but AT1 or AT2 expression was increased in human liver cancer tissues. In addition, AT1 staining by IHC was increased, but AT2 staining was decreased in human liver cancer tissues, and AT1 and AT2 expression were predominantly cytoplasmic (Fig.1C). 
A

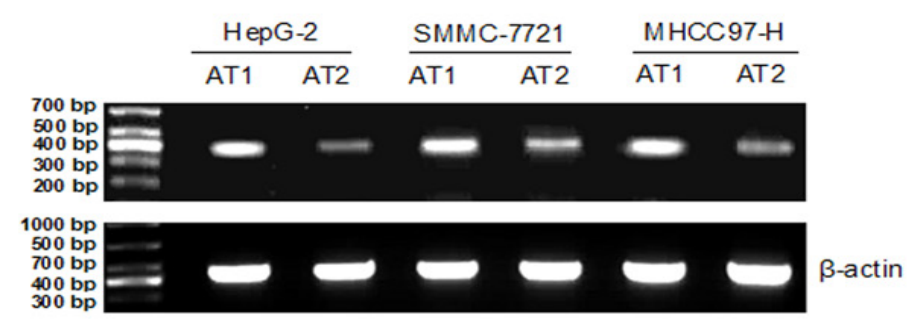

B

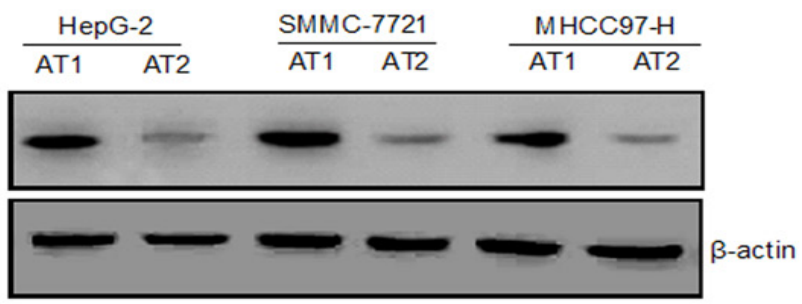

$\mathrm{C}$

Non-tumoral

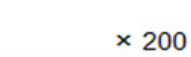

$\times 200 \times 400$

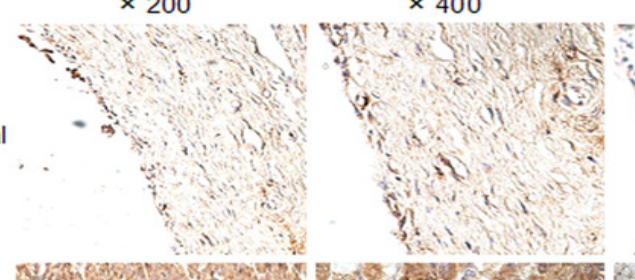

Liver can cer
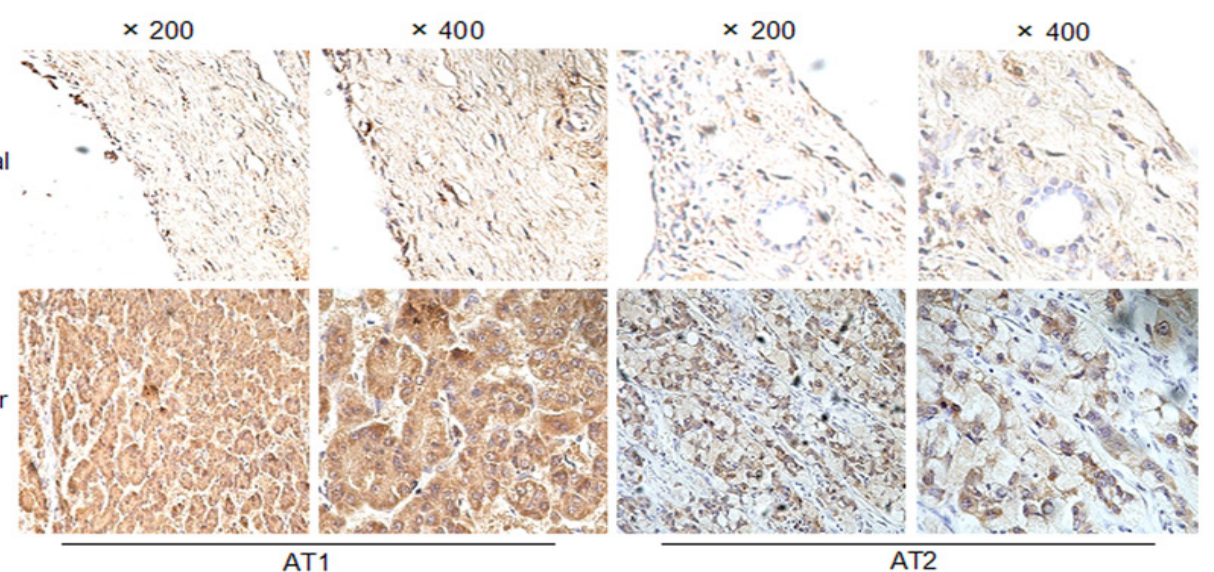

Fig. 1. Expressions of angiotensin II (Ang II) receptors in hepatocellular carcinoma (HCC). (A) mRNA expressions of Ang II receptors (AT1 and AT2) in Human HCC cell lines (HepG-2, SMMC-7721, MHCC97-H). (B) Protein expressions of Ang II receptors (AT1 and AT2) in Human HCC cell lines (HepG-2, SMMC-7721, MHCC97-H). (C) Expressions of Ang II receptors (AT1 and AT2) in non-cancerous liver tissues and liver cancer tissues.

\section{Ang II induced cell growth and proliferation in HCC cell lines}

To study whether Ang II was related to growth and proliferation of HCC cell lines (HepG2, SMMC-7721, MHCC97-H), we firstly performed MTT assay. Compared with control, HCC cell lines induced by Ang II showed higher growth in a time and concentration-dependent fashion. And treatment of Ang II in higher concentrations (1000 $\mathrm{nM}$ ) resulted in a significant enhancement of tumor cell viability at $72 \mathrm{~h}$ (Fig. 2A). Moreover, to evaluate the effect of Ang II on proliferation of HCC cells, BrdU ELISA assay was performed. Compared with control, HCC cell lines induced by Ang II showed higher proliferation in a time and concentrationdependent manner. And treatment of Ang II in higher concentrations (1000 nM) resulted in a significant increase of tumor cell proliferation at $72 \mathrm{~h}$ (Fig. 2B). We further analyzed the colony formation ability of HCC cell lines induced by Ang II using crystal violet staining. Compared with control, colony number was remarkably increased after the induction of Ang II. And treatment of Ang II in higher concentrations (1000 nM) resulted in a significant 


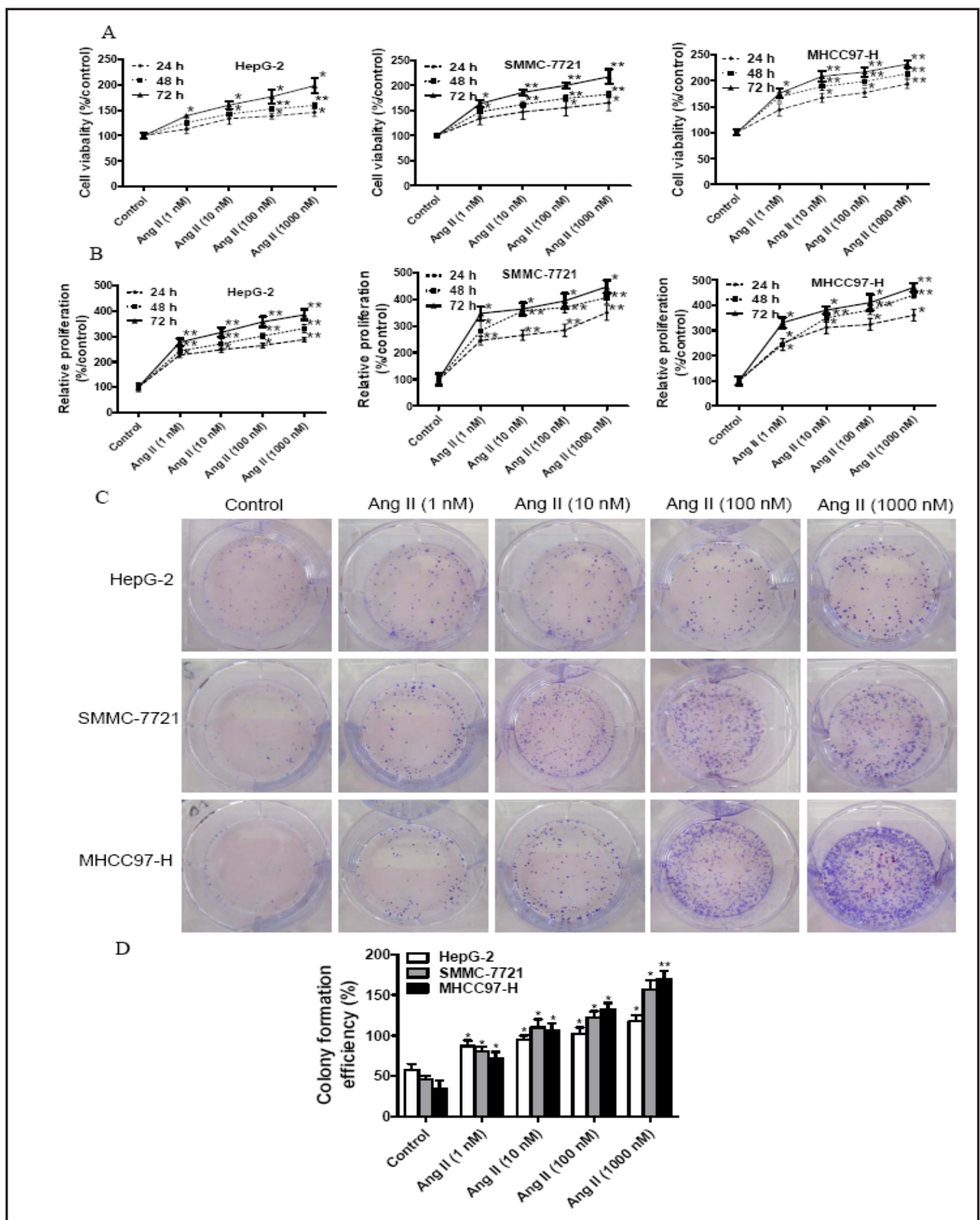

Fig. 2. Ang II-induced cell growth and proliferation in HCC cell lines (HepG-2, SMMC-7721, MHCC97-H). (A) Relative viability (MTT-assay) of HCC cell lines was determined after application of Ang II (1, 10, 100 and $1000 \mathrm{nM}$ ) at different time points $(24,48$, and $72 \mathrm{~h})$. (B) Relative proliferation (BrdU ELISA-assay) of HCC cell lines was measured after application of Ang II $(1,10,100$ and $1000 \mathrm{nM})$ at different time points $(24,48$, and $72 \mathrm{~h}$ ). (C) The representatives of colony formation were shown. (D) The clone formation efficiency of cells was expressed as the number of colonies formed/200 cells seeded. Data are presented as mean \pm SEM from three independent experiments. Statistical significance was calculated using Student's $t$ test. $* P<0.05$, ** $P<0.01$ vs. control.

increase of tumor cell proliferation (Fig. 2C and 2D). However, as shown by flow cytometry analysis, application of Ang II (1, 10, 100 and $1000 \mathrm{nM})$ for $48 \mathrm{~h}$, resulted in a minimal 


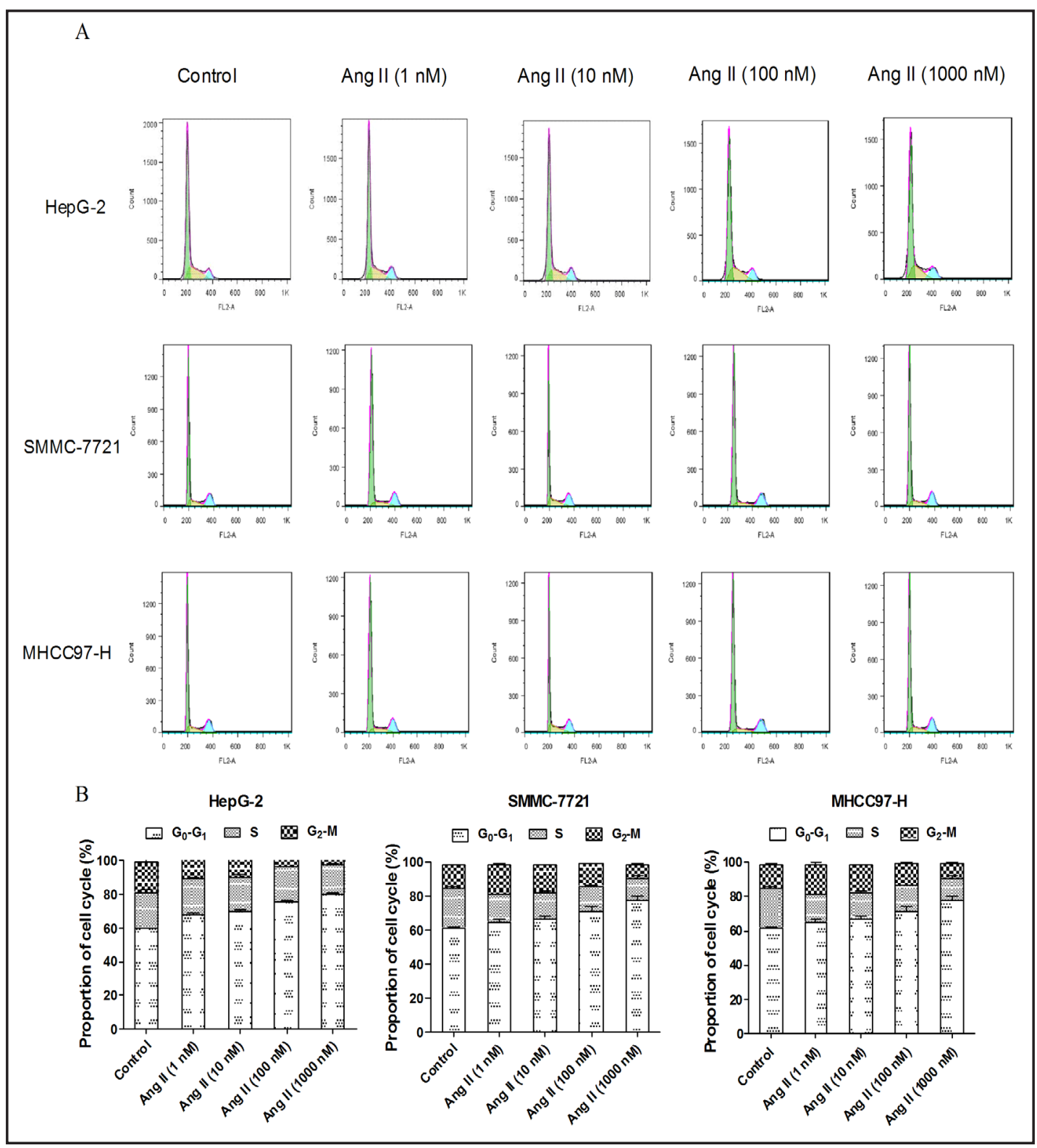

Fig. 3. Effect of Ang II on cell cycle in HCC cell lines (HepG-2, SMMC-7721, MHCC97-H). (A)Ang II-induced cell cycle was determined by flow cytometry at $48 \mathrm{~h}$. (B) Proportion of cell cycle was analyzed. Data are presented as mean \pm SEM from three independent experiments. All values differed significantly from the control groups by at least $P<0.05$, as evaluated by Student's $t$ test.

increase in the percentage of HepG-2、SMMC-7721 and MHCC97-H cells in the G0/G1 phase, while no statistically significant alterations were observed for HCC cells lines (Fig. 3). The results illustrated that Ang II induced cell growth and proliferation in HCC cells in a time and concentration-dependent fashion.

\section{Ang II-induced C-myc immunofluorescent expression in HCC cell lines}

Overexpression of $\mathrm{C}$-myc promotes oncogenic transformation and tumorigenesis by activating the transcription of target genes that drive cell proliferation [23]. C-myc is among the most potent oncogenes associated with HCC development in mice [24]. To examine whether Ang II induced C-myc immunofluorescent expression in HCC cell lines, 


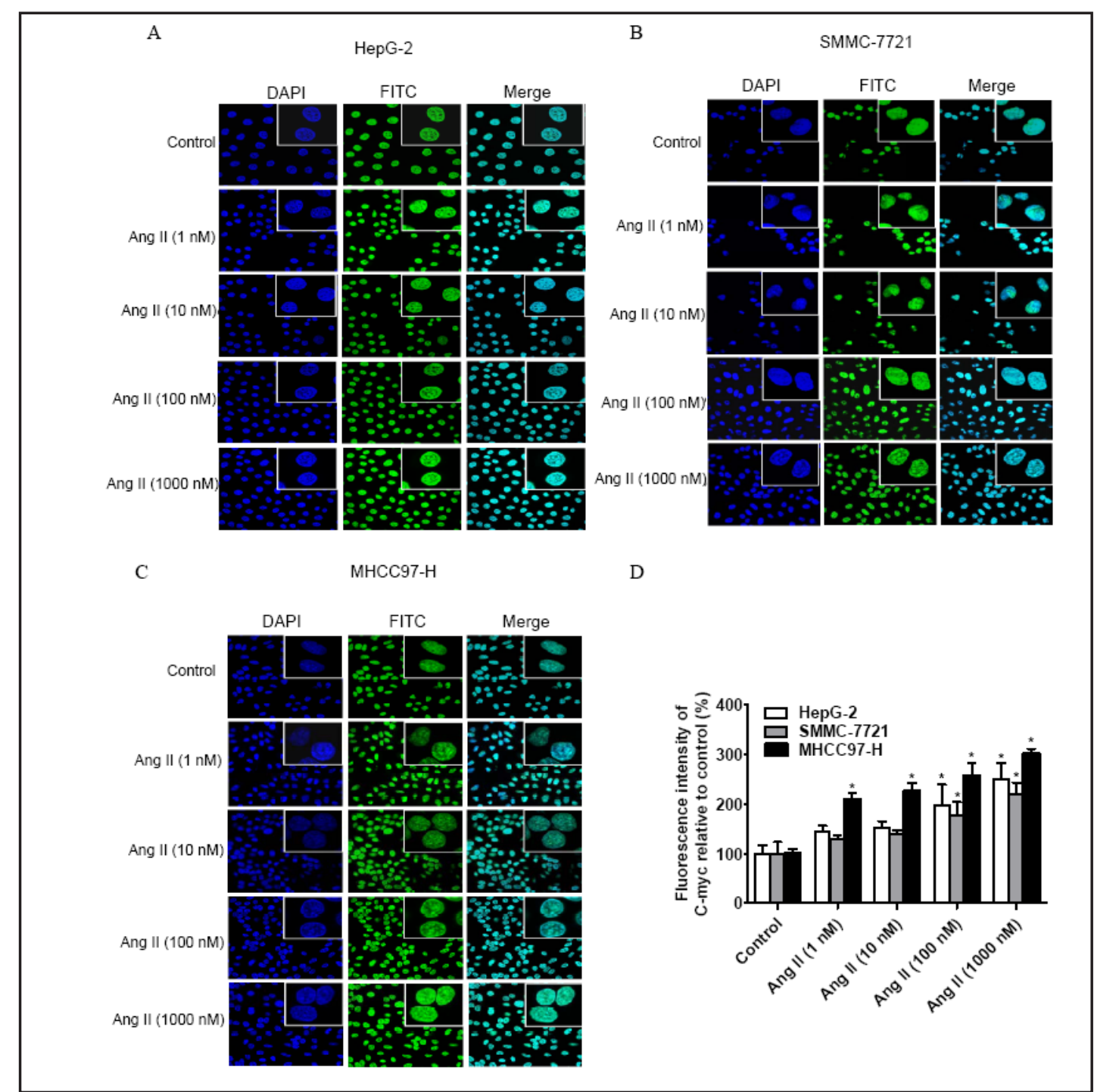

Fig. 4. Immunofluorescent analysis of C-myc expression induced by Ang II in HCC cell lines (HepG-2, SMMC7721, MHCC97-H). Cells were incubated with Ang II (1, 10, 100 and $1000 \mathrm{nM}$ ) for 48 h. (A-C) C-myc expression was identified with immune-cytofluorescence in HCC cell lines. (D) Fluorescent intensity of C-myc was also detected. Data are presented as mean \pm SEM from three independent experiments. Statistical significance was calculated by Student's $t$ test. ${ }^{*} P<0.05$ vs. control.

cells were incubated with Ang II (1, 10, 100 and $1000 \mathrm{nM})$ for $48 \mathrm{~h}$, and expression were identified with immunocytofluorescence. The results showed that Ang II enhanced C-myc immunofluorescent expression in HCC cells, and treatment of Ang II in higher concentrations $(1000 \mathrm{nM})$ resulted in a significant increase of C-myc immunofluorescent expression (Fig. 4).

\section{Ang II-induced TNF- $\alpha$ and CRP secretion in HCC cell lines}

HCC is a typical inflammation-related malignancy, and inflammation has been implicated in the process of hepatocarcinogenesis $[25,26]$.TNF- $\alpha$, a multi-functional cytokine, plays an important role in cellular proliferation leading to liver regeneration or even hepatocarcinogenesis [27]. Elevated circulating levels of pro-inflammatory cytokine CRP have been reported to associate with an increased risk for several types of cancers and cancer prognosis, including HCC $[28,29]$. To explore effects of Ang II on TNF- $\alpha$ and CRP secretion in HCC cell lines, cells were incubated with Ang II $(1,10,100$ and $1000 \mathrm{nM})$ for 24, 


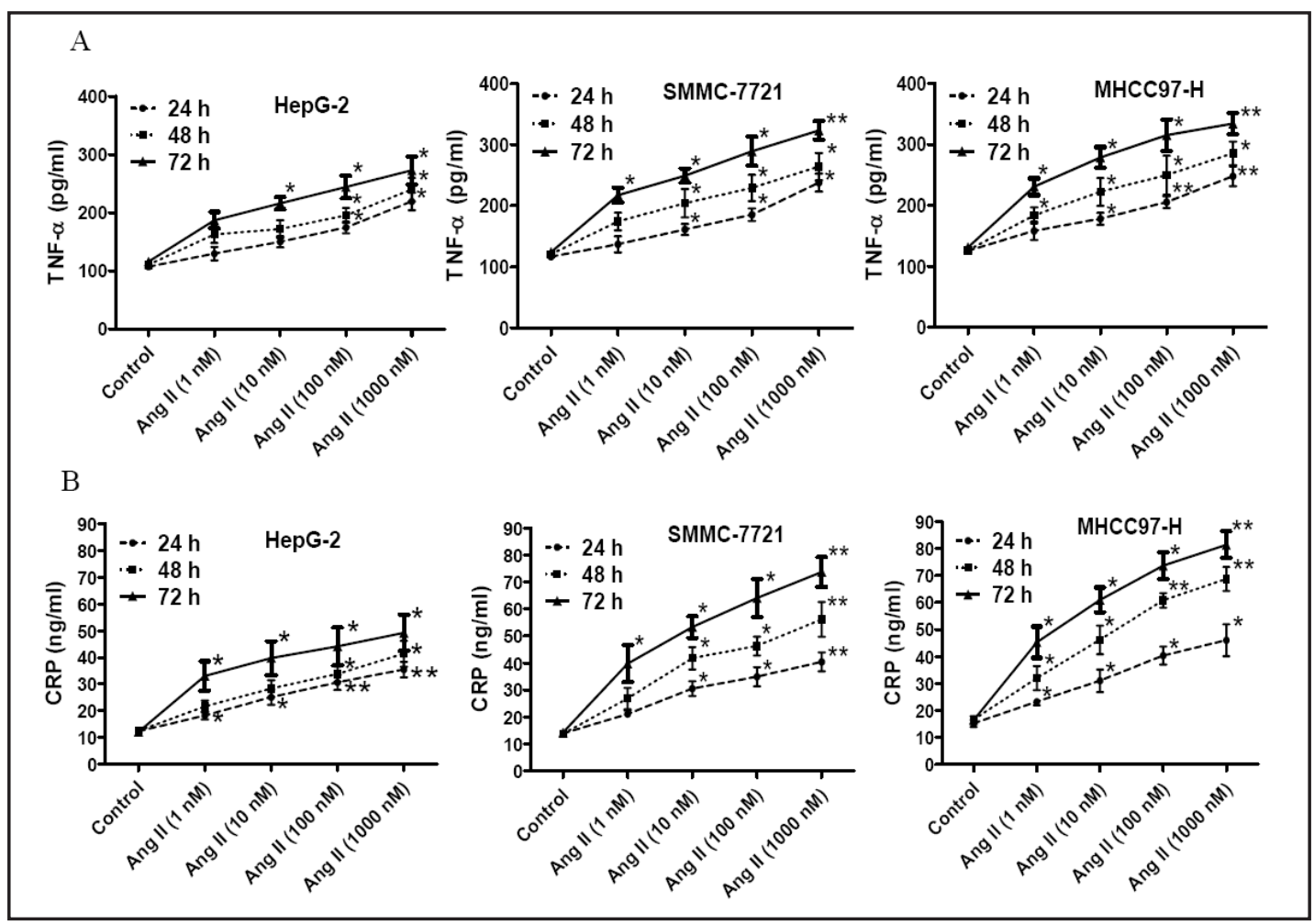

Fig. 5. Ang II-induced TNF- $\alpha$ and CRP secretion in HCC cell lines (HepG-2, SMMC-7721, MHCC97-H). Cells were incubated with Ang II (1, 10, 100 and $1000 \mathrm{nM})$ for 24, 48 and $72 \mathrm{~h}$. Concentration of TNF- $\alpha$ (A) and CRP (B) in the supernatant was measured by ELISA. Data are presented as the mean \pm SEM from three independent experiments. Statistical significance was calculated by Student's $t$ test. ${ }^{*} P<0.05,{ }^{* *} P<0.01$ vs. control.

48 and $72 \mathrm{~h}$. The results illustrated that Ang II elevated TNF- $\alpha$ and CRP secretion in HCC cells in a time and concentration-dependent fashion (Fig. 5).

Ang II-induced C-myc, PCNA, TNF- $\alpha, C R P$ mRNA and protein expressions in HCC cell lines

We further investigated effects of Ang II on C-myc, PCNA, TNF- $\alpha$ and CRP mRNA and protein expressions in HCC cell lines (HepG-2, SMMC-7721, MHCC97-H). Cells were incubated with different concentrations of Ang II (1, 10, 100 and $1000 \mathrm{nM})$ for $48 \mathrm{~h}, \mathrm{C}$-myc, PCNA, TNF- $\alpha$ and CRP mRNA levels and protein expressions were analyzed by quantitative real-time PCR and western blot. As shown in Fig. 6, Ang II upregulated C-myc, PCNA, TNF- $\alpha$ and CRP mRNA levels and protein expressions in HCC cells in a concentration-dependent manner.

Ang II-induced cellular proliferation and TNF- $\alpha$ and CRP generations via AT1 in HCC cell lines

The above-mentioned results suggest that Ang II might induce cellular proliferation , TNF- $\alpha$ and CRP generations in HCC cell lines. To assess the role of AT1 and AT2 in the process, we further evaluated effects of the AT1 inhibitor losartan and the AT2 inhibitor PD123319 pretreatment on cellular proliferation, TNF- $\alpha$ and CRP generations in Ang II- induced HCC cell lines. As shown in Fig. 7, $1 \mu \mathrm{M}$ of losartan remarkably attenuated Ang II-induced cellular proliferation, TNF- $\alpha$ and CRP generations in HCC cell lines, however, $10 \mu \mathrm{M}$ of PD123319 had no effect. Consequently, these results demonstrated that Ang II induced cellular proliferation , TNF- $\alpha$ and CRP generations via AT1 in HCC cells. 


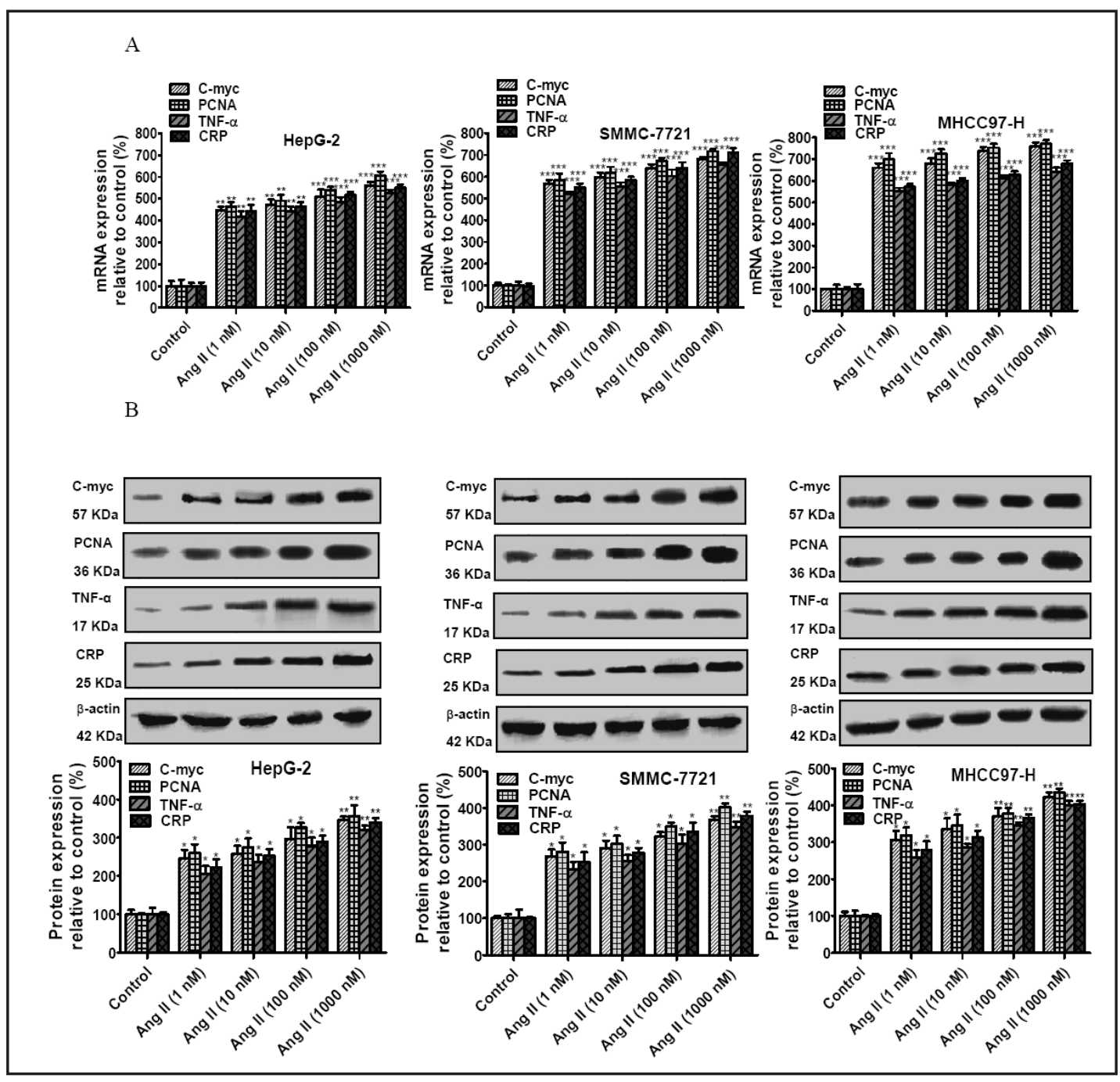

Fig. 6. Ang II-induced C-myc, PCNA, TNF- $\alpha$ and CRP mRNA and protein expressions in HCC cell lines (HepG2, SMMC-7721, MHCC97-H). Cells were incubated with different concentrations of Ang II (1, 10, 100 and $1000 \mathrm{nM}$ ) for $48 \mathrm{~h}$. (A) C-myc, PCNA, TNF- $\alpha$ and CRP mRNA levels were analyzed by quantitative real-time PCR after normalization to -actin mRNA. (B) C-myc, PCNA, TNF- $\alpha$ and CRP protein expressions were measured by western blot. Data are presented as mean \pm SEM from three independent experiments. Statistical significance was calculated using Student's $t$ test. ${ }^{*} P<0.05$, ${ }^{* *} P<0.01,{ }^{* * *} P<0.001$ vs. control.

AT1 siRNA decreased Ang II-induced C-myc, PCNA, TNF- $\alpha$ and CRP mRNA and protein expressions in HCC cell lines

Considering that the AT1 inhibitor losartan reduced Ang II-induced cellular proliferation, TNF- $\alpha$ and CRP generations in HCC cells, we further analyzed the impact of AT1 deficiency on Ang II-induced C-myc, PCNA, TNF- $\alpha$ and CRP mRNA and protein expressions in HCC cell lines. Cells were transiently transfected with AT1 siRNA for $48 \mathrm{~h}$, and then AT1 mRNA and protein expressions were tested. Knock down efficiency of AT1 was 61.17\% (HepG2), $60.83 \%$ (SMMC-7721) and 70.33\% (MHCC97-H) as determined by quantitative realtime PCR, and knock down efficiency of AT1 was 63.17\% (HepG-2), 60.00\% (SMMC-7721) and $69.83 \%$ (MHCC97-H) as determined by western blot (Fig. 8A and 8B). These results suggested that silencing efficiency of HCC cells should be accepted for all the experiments. Next, the transfected cells were stimulated with Ang II (100 nM) for $48 \mathrm{~h}$. As described in Fig. 8C and 8D, compared with the negative control, stimulating the cells with Ang II resulted in 


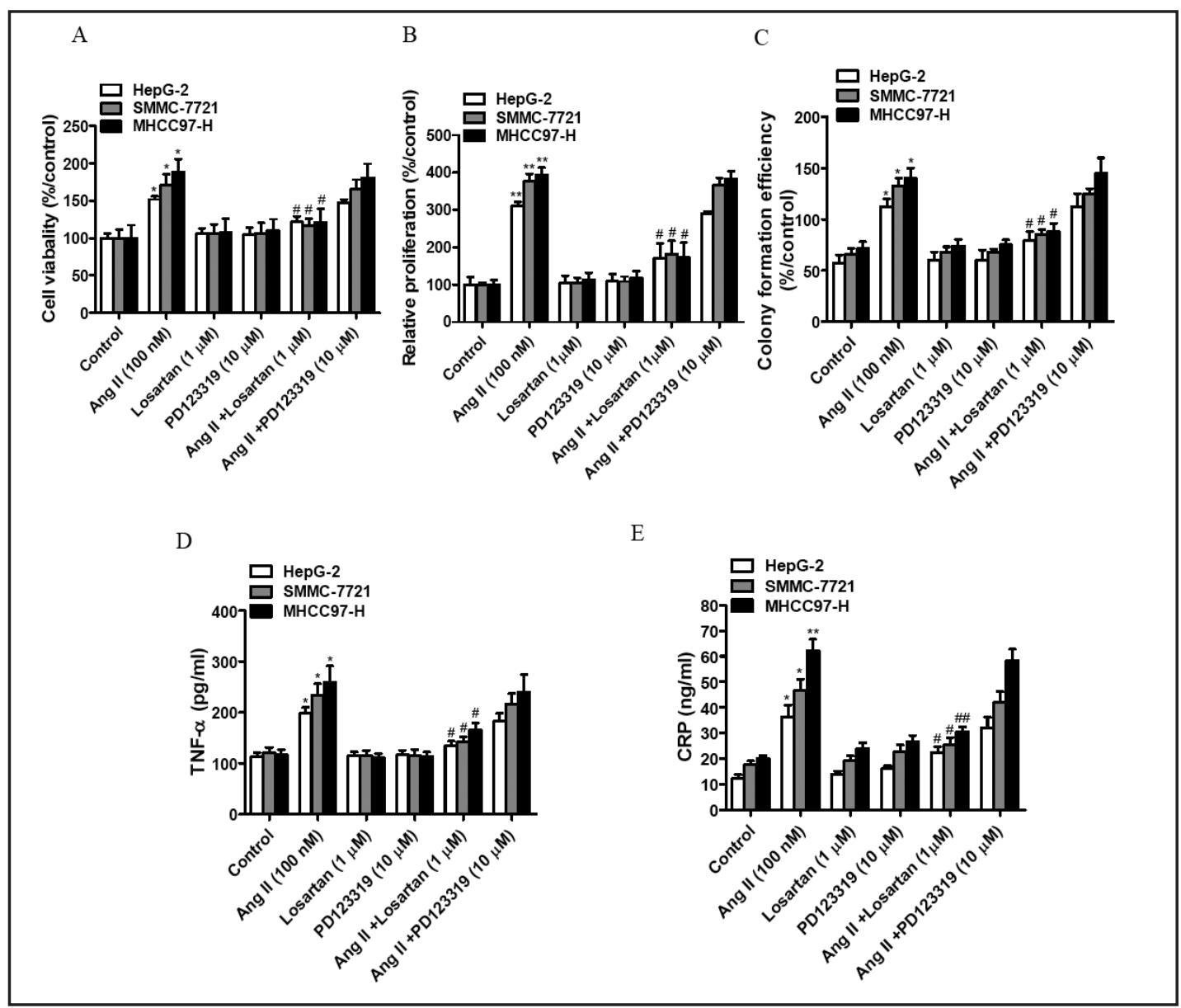

Fig. 7. Ang II-induced cellular proliferation and TNF- $\alpha$ and CRP generation partly via AT1 in HCC cell lines (HepG-2, SMMC-7721, MHCC97-H). Cells were pretreated with Losartan (1 $\mu \mathrm{M})$ and PD123319 (10 $\mu \mathrm{M})$ for $1 \mathrm{~h}$ and stimulated with Ang II (100 nM) for $48 \mathrm{~h}$. (A) Relative viability (MTT-assay) of HCC cell lines was determined. (B) Relative proliferation (BrdU ELISA-assay) of HCC cell lines was assayed. (C) The clone formation efficiency of cells was also detected. Concentration of TNF- $\alpha$ (D) and CRP (E) in the supernatant was measured by ELISA. Data are presented as mean \pm SEM from three independent experiments. Significance was determined by one-way ANOVA. ${ }^{*} P<0.05$, ${ }^{* *} P<0.01$ vs. control; ${ }^{\#} P<0.05$, ${ }^{\# \# ~} P<0.01$ vs. Ang II.

elevation of C-myc, PCNA, TNF- $\alpha$ and CRP mRNA and protein expressions, whereas lack of AT1 dramatically decreased Ang II-induced C-myc, PCNA, TNF- $\alpha$ and CRP mRNA and protein expressions in HCC cell lines, further suggesting that Ang II enhanced C-myc, PCNA, TNF- $\alpha$ and CRP mRNA and protein expressions via AT1.

Ang II-elicited activation of AT1/PKC/NF- $\kappa B$ signaling pathway in HCC cell lines

To evaluate downstream effectors of AT1, AT1 was knocked down in HCC cell lines and analyzed for PKC expression. We further explored the role of AT1 in Ang II-induced PKC expression, cells were transiently transfected with AT1 siRNA for $48 \mathrm{~h}$, and subsequently stimulated with Ang II (100 nM) for $48 \mathrm{~h}$. As shown in Fig. 9A, Ang II-induced PKC protein expression was potentally prohibited by AT1 siRNA, manifesting that AT1 is required for Ang II-induced PKC expression in HCC cell lines. Then we observed whether the blockade of PKC was involved in Ang II-induced NF- $\kappa B$ activation in HCC cell lines. Cells were pretreated with the specific PKC inhibitor chelerythrine $(\mathrm{CH}, 5 \mu \mathrm{M})$ for $1 \mathrm{~h}$ and subsequently stimulated with Ang II (100 nM). As shown in Fig. 9B, 9C and 9D, CH significantly inhibited NF- $\mathrm{BB}$ protein expression and phosphorylation induced by Ang II in HCC cell lines. We also assessed NF- $\mathrm{B}$ 


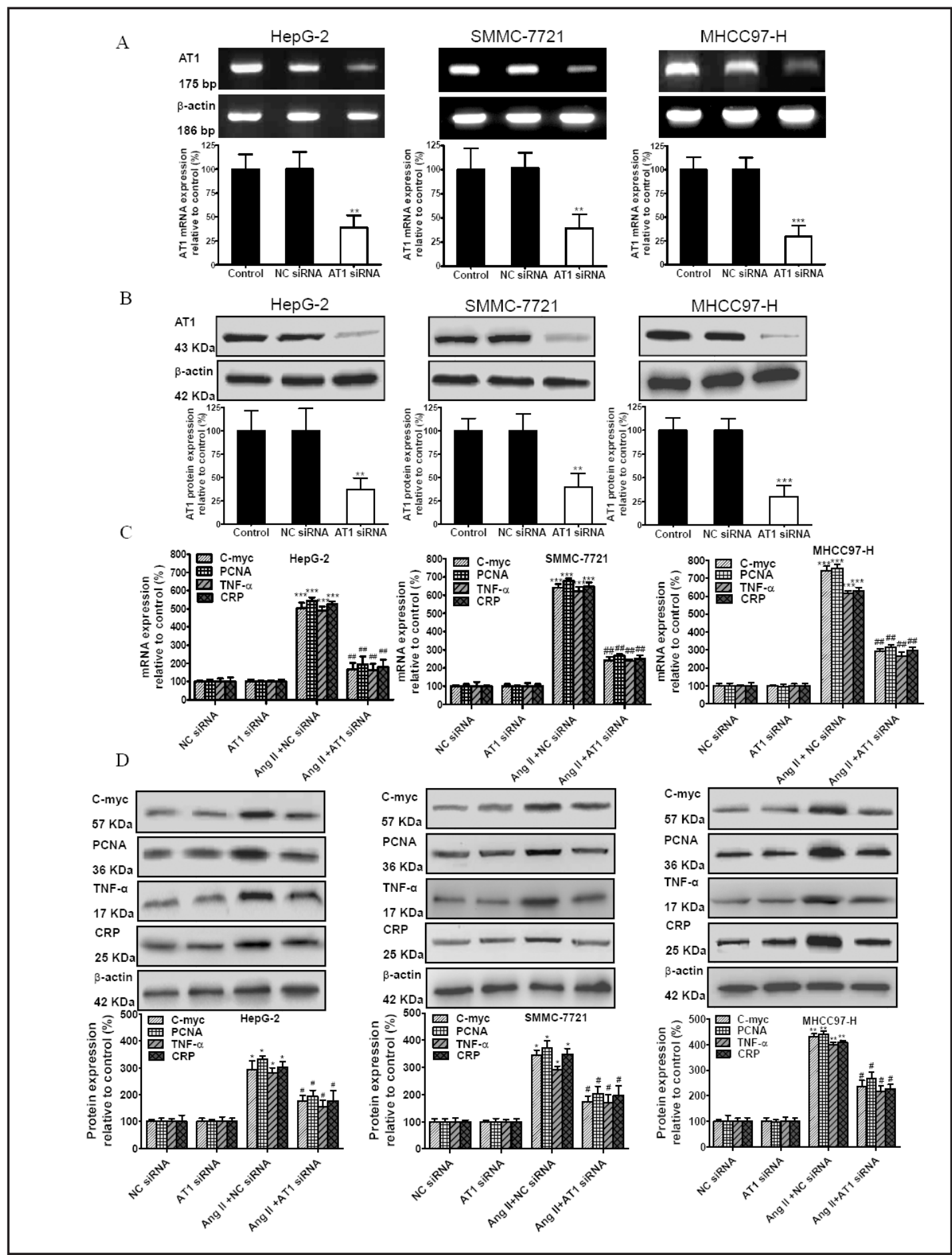

Fig. 8. Effect of AT1 siRNA on Ang II-induced C-myc, PCNA, TNF- $\alpha$ and CRP mRNA and protein expressions in HCC cell lines (HepG-2, SMMC-7721, MHCC97-H). After application of negative control siRNA (NC siRNA) or AT1 siRNA for $48 \mathrm{~h}$, cells were stimulated with Ang II (100 nM) for $48 \mathrm{~h}$. (A) mRNA levels of AT1 in HCC cell lines were analyzied by reverse transcription-polymerase chain reaction (RT-PCR) and quantitative real-time PCR. (B) Protein expression of AT1 in HCC cell lines were detected by western blot. (C) C-myc, PCNA, TNF- $\alpha$ and CRP mRNA levels were analyzed by quantitative real-time PCR after normalization to $\beta$-actin mRNA. (D) C-myc, PCNA, TNF- $\alpha$ and CRP protein expressions were measured by western blot. Data are presented as mean \pm SEM from three independent experiments. Significance was determined by two-way ANOVA. ${ }^{*} P<0.05,{ }^{* *} P<0.01,{ }^{* * *} P<0.001$ vs. NC siRNA; ${ }^{\#} P<0.05,{ }^{\# \#} P<0.01$ vs. Ang II +NC siRNA. 
Fig. 9. Ang II-elicited activation of AT1/PKC/ $\mathrm{NF}-\kappa \mathrm{B}$ signaling pathway in HCC cell lines (HepG-2, SMMC-7721, MHCC97-H). (A) Ang II-induced PKC protein expression through AT1. (B) Involvement of PKC in Ang II-induced NF$\kappa \mathrm{B}$ protein expression and phosphorylation. (C) Dual luciferase assay was performed 48 hours after adding Ang II and PKC inhibitor CH. Relative $N F-\kappa B$ luciferase activity was normalized to Renilla luciferase activity. Data are presented as mean \pm SEM from three independent experiments. Significance was determined by twoway ANOVA. ${ }^{*} P<0.05$ vs. control; ${ }^{*} P<0.05$ vs. Ang II; ${ }^{\dagger} P<0.05$ vs. NC siRNA; ${ }^{\S} P<0.05$ vs. Ang II+NC siRNA.

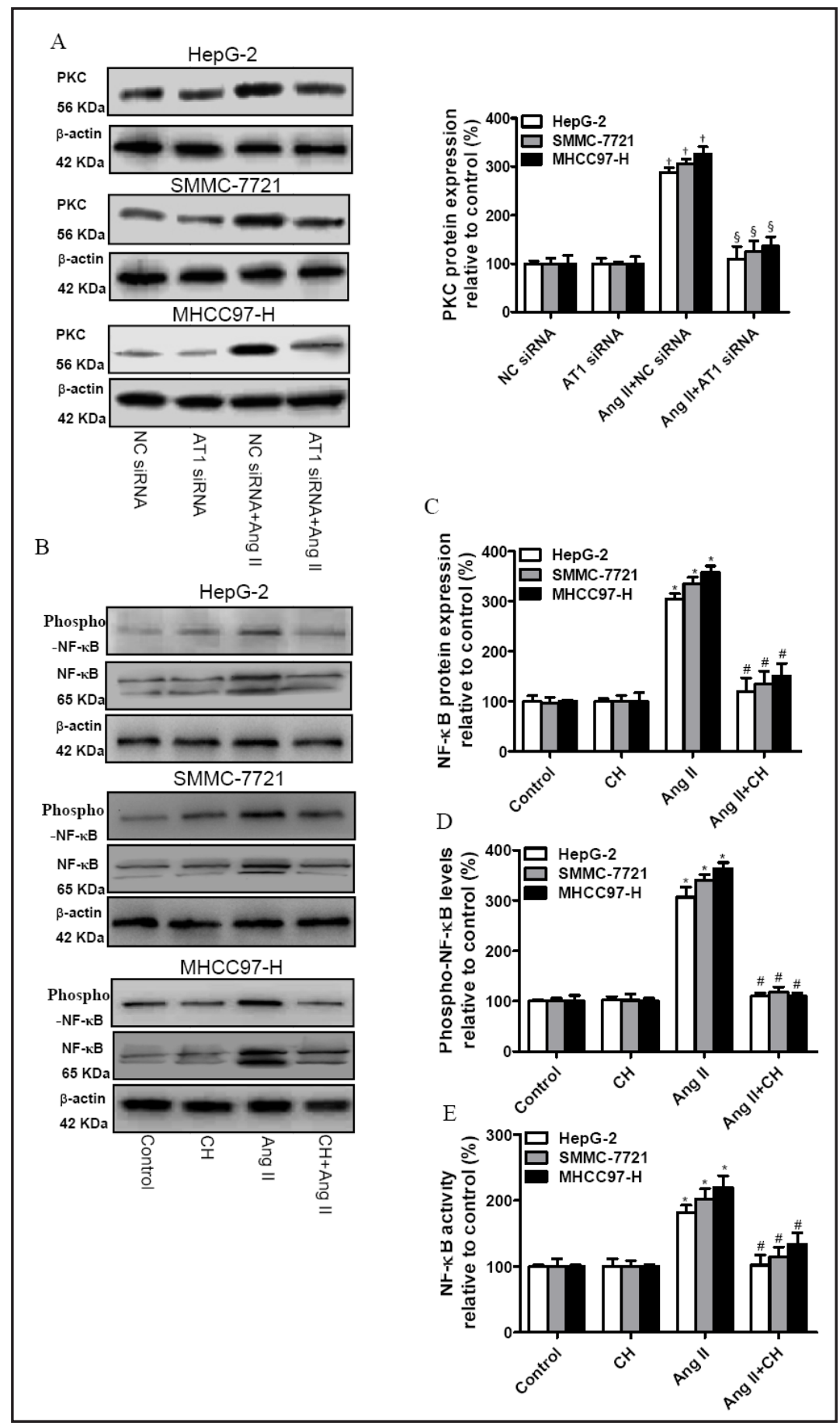

activation induced by Ang II in HCC cells with NF-кB-Luc reporter vector. As described in Fig. 9E, treatment of Ang II led to a significant increase of NF- $\mathrm{BB}$ luciferase activity in HCC cell lines. $\mathrm{CH}$ obviously prohibited NF- $\kappa \mathrm{B}$ luciferase activity induced by Ang II in HCC cell lines. The above results indicated that Ang II-induced NF- $\kappa B$ activation was PKC dependent. In combination, Ang II elicited activation of AT1/PKC/NF- $\kappa B$ signaling pathway in HCC cells.

Ang II-induced cellular proliferation, C-myc, PCNA, TNF- $\alpha$ and CRP generations and expressions via $N F-\kappa B$ in HCC cell lines

It is reported that NF- $\kappa B$ signaling is frequently activated in HCC $[30,31]$. NF- $\kappa B$ controls the expression of a large number of downstream genes that regulate cell proliferation, 


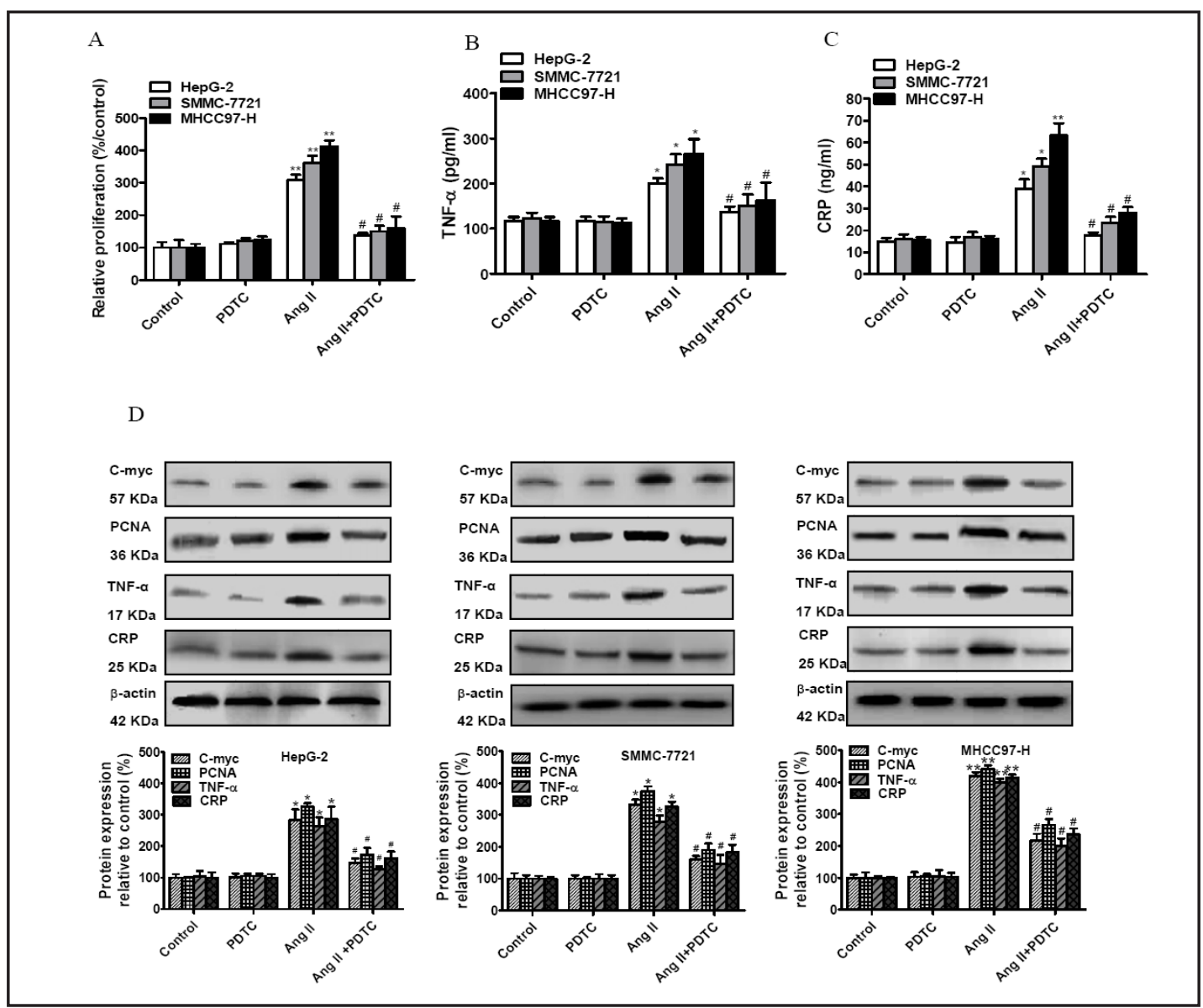

Fig. 10. Ang II-induced cellular proliferation, C-myc, PCNA, TNF- $\alpha$ and CRP generations and expressions via NF- $\kappa$ B in HCC cell lines (HepG-2, SMMC-7721, MHCC97-H). Cells were pretreated with NF- $\kappa$ B inhibitor PDTC $(100 \mu \mathrm{M})$ for $1 \mathrm{~h}$ and stimulated with Ang II (100 nM) for $48 \mathrm{~h}$. (A) Relative proliferation (BrdU ELISA-assay) of HCC cell lines was assayed. Concentration of TNF- $\alpha$ (B) and CRP (C) in the supernatant was measured by ELISA. (D) C-myc, PCNA, TNF- $\alpha$ and CRP protein expressions were measured by western blot. Data are presented as mean \pm SEM from three independent experiments. Significance was determined by one-way ANOVA. ${ }^{*} P<0.05,{ }^{* *} P<0.01$ vs. control; ${ }^{\#} P<0.05$ vs. Ang II.

survival and inflammatory responses [2, 32]. To clarify whether Ang II- induced cellular proliferation, C-myc, PCNA, TNF- $\alpha$ and CRP generations and expressions are associated with NF- $\kappa B$ activation in HCC cell lines, cells were pretreated with the NF- $\kappa B$ inhibitor PDTC $(100 \mu \mathrm{M})$ for $1 \mathrm{~h}$ and subsequently stimulated with Ang II $(100 \mathrm{nM})$ for $48 \mathrm{~h}$. The results demonstrated that PDTC evidently inhibited cellular proliferation induced by Ang II in HCC cell lines (Fig. 10A). As shown in Fig. 10 B and 10 C, PDTC markedly inhibited TNF- $\alpha$ and CRP generations induced by Ang II in HCC cell lines, suggesting that Ang II induced TNF- $\alpha$ and CRP productions via NF- $\kappa$ B. The similar results to TNF- $\alpha$ and CRP productions were achieved for C-myc, PCNA, TNF- $\alpha$ and CRP protein expressions (Fig. 10D). Taken together, these results implied that Ang II induced cellular proliferation, C-myc, PCNA, TNF- $\alpha$ and CRP generations and expressions in HCC cells via NF- $\mathrm{KB}$ activation.

\section{Discussion}

The pathogenesis of HCC is mainly characterized by persistent cycles of liver injury, inflammation, and compensatory hepatocyte proliferation [2,33]. During chronic inflamma- 


\section{Cellular Physiology Cell Physiol Biochem 2016;39:13-32 \\ \begin{tabular}{l|l|l} 
and BiOChemistry & $\begin{array}{l}\text { DOI: 10.1159/000445602 } \\
\text { Published online: June 20, } 2016\end{array}$ & $\begin{array}{l}\text { C } 2016 \text { The Author(s). Published by S. Karger AG, Basel } \\
\text { www.karger.com/cpb }\end{array}$
\end{tabular} \\ Ji et al.: Angiotensin II Enhances Proliferation and Inflammation via AT1/ PKC/NF- $\mathrm{B}$}

tion of the liver, hepatocyte proliferation is activated by local and infiltrated immune cells through paracrine signals involving cytokines, such as TNF- $\alpha$, IL-6 and IL-1 [34]. There is now substantial evidence that Ang II behaves as an endogenous pro-inflammatory molecule and plays a significant role in HCC. Additionally, our previous findings imply that Ang II induces angiogenic factors production partly via AT1/JAK2/STAT3/SOCS3 signaling pathway in MHCC97H cells, which is involved in the metastasis and progress of HCC [6]. Currently, the molecular link between Ang II, proliferation and inflammation are not fully known, thus our study is beginning to unravel the underlying mechanism in HCC.

Ang II, the key effector in the RAS, acts through two well-defined receptors: AT1 and AT2 $[35,36]$. Recent study reported that AT1 expression was associated with enhance angiogenesis and cellular proliferation rate, but no relationship was found with AT2 in breast cancer [8]. Consistent with these results, in the present study, we found increased expression of AT1 and decreased expression of AT2 in HCC cells and tissues. Next, to investigate the major role of Ang II in HCC cells, we selected three different HCC cell lines (HepG-2, SMMC7721 and MHCC97-H) and carefully evaluated the direct effect of Ang II on proliferation and inflammation of these cells. We demonstrated that Ang II could significantly enhance cell growth and proliferation using MTT, BrdU ELISA and plate colony formation assay. Albeit Ang II slightly increased the percentage of HCC cells in the G0/G1 phase using flow cytometry analysis, no statistically significant alterations were shown. Further studies suggested that Ang II could directly induce expressions of proliferation associated proteins (C-myc and PCNA), and productions of inflammatory cytokines (TNF- $\alpha$ and CRP) in HCC cell lines. Interestingly, blocking AT1 and AT1 siRNA evidently inhibited Ang II-induced cell proliferation and inflammatory responses in HCC cell lines. More importantly, these effects may be mediated by AT1/PKC/NF- $\mathrm{KB}$ signaling pathway in HCC cell lines.

C-myc is a basic helix-loop-helix leucine zipper (HLH-ZIP) transcription factor [37]. Overexpression of $\mathrm{C}$-myc promotes oncogenic transformation and tumorigenesis by activating the transcription of target genes that drive cell proliferation and stimulate angiogenesis and repress cell differentiation [38]. C-myc is also considered to be oncogene and frequently overexpressed in HCC [39-41]. Our present results revealed that Ang II enhanced C-myc immunofluorescent expression in HCC cell lines and the expression was predominantly cell nucleus. Further studies showed that Ang II upregulated C-myc mRNA and protein expressions in HCC cell lines. PCNA is a nuclear antigen expressed in proliferating cells in all stages of the cell cycle except stage G0 and serves as a marker for proliferation. Other study has proved that PCNA strong positive staining is seen in the nucleus in HCC [42]. In the present study, Ang II remarkably increased PCNA mRNA and protein expressions in HCC cell lines. And co-expression patterns such as high C-myc with high PCNA expression are closely related to cell proliferation, finally resulting in the increased risk of HCC progression. Thus, aside from the direct effects of Ang II on inducing cell growth and proliferation in HCC cell lines, Ang II could enhance proliferation of HCC cell lines by targeting proliferation associated proteins C-myc and PCNA.

During diethylnitrosamine-induced HCC, a variety of pro-inflammatory cytokines have been identified to drive a select group of hepatocytes to undergo compensatory proliferation to induce hepatocarcinogenesis [43]. Among them, TNF- $\alpha$ is likely to play a central role in tumorigenesis, as it has been reported that mice deficient with TNF- $\alpha$ is protected from the cancer development $[44,45]$. Furthermore, CRP is considered to play a major role in cancer development $[28,29]$. Our study demonstrated that Ang II could directly induce inflammatory cytokines TNF- $\alpha$ and CRP productions in HCC cell lines. Therefore, we could not exclude the possibility that persistently higher levels of TNF- $\alpha$ and CRP induced by Ang II are considered to help maintain a favorable microenvironment to accelerate HCC progression. In addition, TNF- $\alpha$ and CRP are likely to further stimulate expressions of the cancer related inflammatory genes in the HCC cell lines.

Based on results above, we further assessed whether Ang II could promote proliferation and inflammation of HCC cell lines through the activation of AT1. Firstly, our present results revealed increased expression of AT1 and decreased expression of AT2 in HCC cells and tissues by RT-PCR, Western Blot and IHC analysis, which is consistent with previous studies $[36,46]$. 


\section{Cellular Physiology Cell Physiol Biochem 2016;39:13-32 \begin{tabular}{l|l|l} 
DOI: 10.1159/000445602 & $\begin{array}{l}\text { C } 2016 \text { The Author(s). Published by S. Karger AG, Basel } \\
\text { www.karger.com/cpb }\end{array}$
\end{tabular} \\ Ji et al.: Angiotensin II Enhances Proliferation and Inflammation via AT1/ PKC/NF- $\mathrm{KB}$}

Fig. 11. A scheme for signaling pathway related to Ang II-elicited proliferation and inflammation in HCC cells. Ang II can activate AT1, which in turn activates the PKC pathway leading to subsequent regulation of NF- $\mathrm{KB}$ and promotion of proliferation and inflammation in HCC cells.

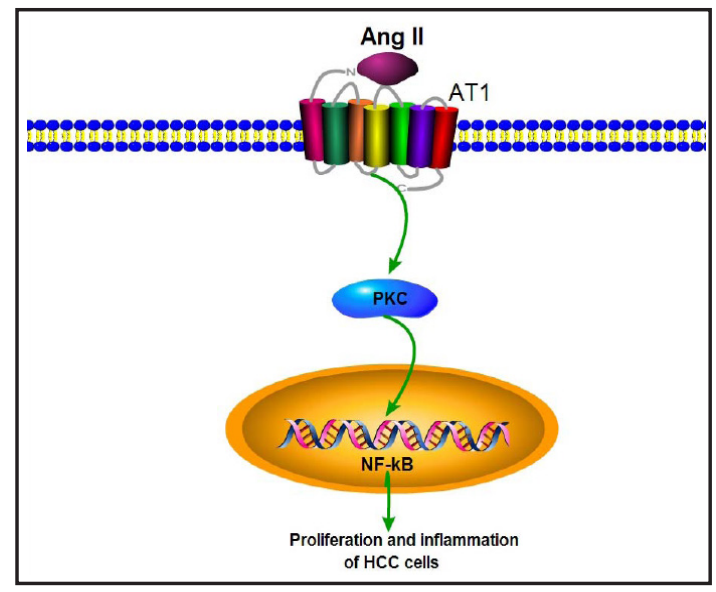

Next, blocking AT1 and AT1 siRNA significantly inhibited Ang II-induced cell proliferation and inflammatory responses in HCC cell lines, thus we could draw the conclusion that Ang II might be an important factor in proliferation and inflammation of HCC via the activation of AT1. To further evaluate downstream effectors of AT1, HCC cells were transiently transfected with AT1 siRNA and subsequently stimulated with Ang II, PKC protein expression was remarkably reduced, which suggested that PKC expression is regulated by Ang II through AT1. Accordingly, Ang II can activate AT1, which in turn activates PKC signaling. PKC is a serine/threonine kinase that plays a key role in several steps of the signal transduction pathway, including cell proliferation, migration, and invasion of HCC $[47,48]$. It has also been demonstrated that inhibition of PKC activity reduces motility and invasion properties of HCC cells [49]. It is tempting to speculate that NF-אB may serve as the down-stream target of PKC signaling pathway. NF- $\mathrm{KB}$ is found in almost all cell types and can be activated by proinflammatory cytokines and endotoxins, and then translocated to the nucleus to regulate inducible gene expression [50,51]. Constitutive NF- $\kappa B$ activation not only correlates closely with inflammatory responses, but also is generally associated with cancer proliferation, survival and progression of HCC $[52,53]$. In this study, Ang II-induced NF$\kappa \mathrm{B}$ expression and activation was significantly suppressed by the $\mathrm{PKC}$ inhibitor $\mathrm{CH}$, providing the proof that PKC is a critical component for Ang II-dependent NF- $\kappa B$ activation in HCC cells. This conclusion is supported by the findings of previous studies, which PKC plays a key role in mediating the NF- $\kappa B$ signaling pathway [54-55]. Finally, the NF- $\mathrm{BB}$ inhibitor PDTC diminished Ang II-mediated productions and expressions of C-myc, PCNA, TNF- $\alpha$ and CRP in HCC cell lines. It seems reasonable to conclude that NF- $\mathrm{KB}$ translocates into the nucleus inducing downstream gene targets including the pro-inflammatory cytokines TNF- $\alpha$ and CRP, thus activation of NF- $\kappa B$ ultimately results in enhanced proliferation of HCC cells.

In conclusion, our data propose that $\mathrm{AT} 1 / \mathrm{PKC} / \mathrm{NF}-\kappa \mathrm{B}$ signaling pathway is necessary for Ang II-induced proliferation and inflammation in HCC cell lines (Fig. 11), which increases our understanding of the pathogenesis and provides clues for developing new strategies against Ang II-related progress of HCC, thus identifying Ang II and AT1 as potential therapeutic targets for the treatment of HCC.

\section{Acknowledgements}

This work was supported by the National Natural Science Foundation of China (No. 81201925), Program for Changjiang Scholars and Innovative Research Team in Universities (PCSIRT No. 1171), the Fundamental Research Funds for the Central Universities of China (No. 2013JDHZ08), and Personnel training Specialized Research Fundation of The Second Affiliated Hospital of Xi'an Jiaotong University of China (No.RC(GG)201404, RC(GG)201502). 


\section{Cellular Physiology Cell Physiol Biochem 2016;39:13-32 and Biochemistry Published online: June 20,2016 $\quad \begin{aligned} & \text { DOI: 10.1159/000445602 } 2016 \text { The Author(s). Published by S. Karger AG, Basel } \\ & \text { www.karger.com/cpb }\end{aligned}$ \\ Ji et al.: Angiotensin II Enhances Proliferation and Inflammation via AT1/ PKC/NF- $\mathrm{BB}$}

\section{Disclosure Statement}

The authors have no conflicts of interest to declare.

\section{References}

1 Villanueva A, Hernandez-Gea V, Llovet JM: Medical therapies for hepatocellular carcinoma: a critical view of the evidence. Nat Rev Gastroenterol Hepatol 2013;10:34-42.

2 He G, Karin M: NF-кB and STAT3 - key players in liver inflammation and Cancer. Cell Research 2011;21:159-168.

3 Whittaker S, Marais R, Zhu AX: The role of signalling pathways in the development and treatment of hepatocellular carcinoma. Oncogene 2010;29:4989-5005.

4 Yang T, Song B, Zhang J, Yang GS, Zhang H, Yu WF, Wu MC, Lu JH, Shen F: STK33 promotes hepatocellular carcinoma through binding to c-Myc. Gut 2016;65:124-133.

5 Yoshiji H, Noguchi R, Ikenaka Y, Kaji K, Aihara Y, Fukui H: Impact of renin- angiotensin system in hepatocellular carcinoma. Curr Cancer Drug Targets 2011;11:431-441.

6 Ji YY, Wang ZD, Li ZF, Li K, Le XF, Zhang T: Angiotensin II induces angiogenic factors production partly via AT1/JAK2/STAT3/SOCS3 signaling pathway in MHCC97H cells. Cell Physiol Biochem 2012;29:863-874.

7 Bataller R, Ginès P, Nicolás JM, Görbig MN, Garcia-Ramallo E, Gasull X, Bosch J, Arroyo V, Rodés J: Angiotensin II induces contraction and proliferation of human hepatic stellate cells. Gastroenterology 2000;118:1149-1156.

8 Arrieta O, Villarreal-Garza C, Vizcaíno G, Pineda B, Hernández-Pedro N, Guevara-Salazar P, WegmanOstrosky T, Villanueva-Rodríguez G, Gamboa-Domínguez A: Association between AT1 and AT2 angiotensin IIreceptor expression with cell proliferation and angiogenesis in operable breast cancer. Tumour Biol 2015;36:5627-5634.

9 Das UN: Angiotensin-II behaves as an endogenous pro-inflammatory molecule. J Assoc Physicians India 2005;53:472-476.

10 Hosseinimehr SJ: The use of angiotensin II receptor antagonists to increase the efficacy of radiotherapy in cancer treatment. Future Oncol 2014;10:2381-2390.

11 Suzuki Y, Ruiz-Ortega M, Lorenzo O, Ruperez M, Esteban V, Egido J: Inflammation and angiotensin II. Int J Biochem Cell Biol 2003;35:881-900.

12 Smith GR, Missailidis S: Cancer, inflammation and the AT1 and AT2 receptors. J Inflamm (Lond) 2004;1:3.

13 Stoyanov E, Ludwig G, Mizrahi L, Olam D, Schnitzer-Perlman T, Tasika E, Sass G, Tiegs G, Jiang Y, Nie T, Kohler J, Schinazi RF, Vertino PM,Cedar H, Galun E, Goldenberg D: Chronic liver inflammation modifies DNA methylation at the precancerous stage of murine hepatocarcinogenesis. Oncotarget 2015;6:11047-11060.

14 Roderburg C, Gautheron J, Luedde T: TNF-dependent signaling pathways in liver cancer: promising targets for therapeutic strategies? Dig Dis 2012;30:500-507.

15 Kinoshita A, Onoda H, Imai N, Iwaku A, Oishi M, Tanaka K, Fushiya N, Koike K, Nishino H, Matsushima M: The C-reactive protein/albumin ratio, a novel inflammation- based prognostic score, predicts outcomes in patients with hepatocellular carcinoma. Ann Surg Oncol 2015;22:803-810.

16 Dang MQ Zhao XC, Lai S, Wang X, Wang L, Zhang YL, Liu Y, Yu XH, Liu Y, Li HH, Xia YL: Gene expression profile in the early stage of angiotensin II-induced cardiac remodeling: a time series microarray study in a mouse model. Cell Physiol Biochem 2015;35:467-476.

17 Marchon C, de Marco Ornelas E, da Silva Viegas KA, Lacchini S, de Souza RR, Fonseca FL, Maifrino LB: Effects of moderate exercise on the biochemical, physiological, morphological and functional parameters of the aorta in the presence of estrogen deprivation and dyslipidemia: an experimental model. Cell Physiol Biochem 2015;35:397-405.

18 Zhang JS, Zhang YL, Wang HX, Xia YL, Wang L, Jiang YN, Li HH, Liu Y: Identification of genes related to the early stage of Angiotensin II-induced acute renal injury by microarray and integrated gene network analysis. Cell Physiol Biochem 2014;34:1137-1151.

19 Wang Z, Zhou J, Fan J, Tan CJ, Qiu SJ, Yu Y, Huang XW, Tang ZY: Sirolimus inhibits the growth and metastatic progression of hepatocellular carcinoma. J Cancer Res Clin Oncol 2009;135:715-722. 


\section{Cellular Physiology Cell Physiol Biochem 2016;39:13-32 and Biochemistry \begin{tabular}{l|l} 
DOI: 10.1159/000445602 & (c) 2016 The Author(s). Published by S. Karger AG, Basel \\
www.karger.com/cpb
\end{tabular} \\ Ji et al.: Angiotensin II Enhances Proliferation and Inflammation via AT1/ PKC/NF- $\mathrm{BB}$}

20 Lai WL, Hung WY, Wong LL, Yuan Z, Leong VY, Lee JM, Ng IO, Jin DY, Ching YP: The centrosomal protein Tax1 binding protein 2 is a novel tumor suppressor in hepatocellular carcinoma regulated by cyclin-dependent kinase 2. Hepatology 2012;56:1770-1781.

21 Jing YY, Han ZP, Sun K, Zhang SS, Hou J, Liu Y, Li R, Gao L, Zhao X, Zhao QD, Wu MC, Wei LX: Toll-like receptor 4 signaling promotes epithelial mesenchymal transition in human hepatocellular carcinoma induced by lipopolysaccharide. BMC Medicine 2012;10:98.

22 Ji YY, Wang ZD, Li ZF, Li K: Interference of suppressor of cytokine signaling 3 promotes epithelialmesenchymal transition in MHCC97H cells. World J Gastroentero 2013;19:866-873.

23 Berg T, Cohen SB, Desharnais J, Sonderegger C, Maslyar DJ, Goldberg J, Boger DL, Vogt PK: Small-molecule antagonists of Myc/Max dimerization inhibit Myc-induced transformation of chicken embryo fibroblasts. Proc Natl Acad Sci USA 2002;99:3830-3835.

24 Vita M, Henriksson M: The Myc oncoprotein as a therapeutic target for human cancer. Semin Cancer Biol 2006;16:318-330.

25 Liao R, Sun TW, Yi Y, Wu H, Li YW, Wang JX, Zhou J, Shi YH, Cheng YF, Qiu SJ, Fan J: Expression of TREM-1 in hepatic stellate cells and prognostic value in hepatitis B related hepatocellular carcinoma. Cancer Sci 2012;103:984-992.

26 Szabo G, Lippai D: Molecular hepatic carcinogenesis: impact of inflammation. Dig Dis 2012;30:243-248.

27 Jang MK, Kim HS, Chung YH: Clinical aspects of tumor necrosis factor- $\alpha$ signaling in hepatocellular carcinoma. Curr Pharm Des 2014;20:2799-2808.

28 Ni XF, Wu P, Wu CP, Ji M, Wu J, Gu XF, Jiang ZX: Elevated serum C-reactive protein, carcinoembryonic antigen and N2 disease are poor prognostic indicators in non-small cell lung cancer. Asia Pac Clin Oncol 2015;11:e22-30.

29 Goyal A, Terry MB, Jin Z, Siegel AB: C-reactive protein and colorectal cancer mortality in us adults. Cancer Epidemiol Biomarkers Prev 2014;23:1609-1618.

30 Ben-Neriah Y, Karin M: Inflammation meets cancer, with NF-kappaB as the matchmaker. Nat Immunol 2011;12:715-723.

31 Liu P, Kimmoun E, Legrand A, Sauvanet A, Degott C, Lardeux B, Bernuau D: Activation of NF-kappa B, AP-1 and STAT transcription factors is a frequent and early event in human hepatocellular carcinomas. J Hepatol 2002;37:63-71.

32 Jiang C, Lin X: Analysis of epidermal growth factor-induced NF- $\mathrm{KB}$ signaling. Methods Mol Biol 2015;1280:75-102.

33 Grivennikov SI, Greten FR, Karin M: Immunity, inflammation, and cancer. Cell 2010;140:883-899.

34 Martin M, Herceg Z: From hepatitis to hepatocellular carcinoma: a proposed model for cross-talk between inflammation and epigenetic mechanisms. Genome Medicine 2012;4:8.

35 Timmermans PB, Wong PC, Chiu AT, Herblin WF, Benfield P, Carini DJ, Lee RJ, Wexler RR, Saye JA, Smith RD: Angiotensin II receptors and angiotensin II receptor antagonists. Pharmacol Rev 1993;45:205-251.

36 Du H, Liang Z, Zhang Y, Jie F, Li J, Fei Y, Huang Z, Pei N, Wang S, Li A, Chen B, Zhang Y, Sumners C, Li M, Li H: Effects of angiotensin II type 2 receptor overexpression on the growth of hepatocellular carcinoma cells in vitroand in vivo. PLoS One 2013;8:e83754.

37 Cheng Q Yuan F, Lu F, Zhang B, Chen T, Chen X, Cheng Y, Li N, Ma L, Tong T: CSIG promotes hepatocellular carcinoma proliferation by activating c-MYC expression. Oncotarget 2015;6:4733-4744.

38 Berg T, Cohen SB, Desharnais J, Sonderegger C, Maslyar DJ, Goldberg J, Boger DL, Vogt PK: Small-molecule antagonists of Myc/Max dimerization inhibit Myc-induced transformation of chicken embryo fibroblasts. Proc Natl Acad Sci USA 2002;99:3830-3835.

39 Schlaeger C, Longerich T, Schiller C, Bewerunge P, Mehrabi A, Toedt G, Kleeff J, Ehemann V, Eils R, Lichter P, Schirmacher P, Radlwimmer B: Etiology-dependent molecular mechanisms in human hepatocarcinogenesis. Hepatology 2008;47:511-520.

40 Li L, Jin R, Zhang X, Lv F, Liu L, Liu D, Liu K, Li N, Chen D: Oncogenic activation of GPC3 by c-myc in human hepatocellular carcinoma. Hepatology 2012;56:1380-1390.

41 Han H, Sun D, Li W, Shen H, Zhu Y, Li C, Chen Y, Lu L, Li W, Zhang J, Tian Y, Li Y: A c-Myc-MicroRNA functional feedback loop affects hepatocarcinogenesis. Hepatology 2013;57:2378-2389.

42 Qiu DM, Wang GL, Chen L, Xu YY, He S, Cao XL, Qin J, Zhou JM, Zhang YX, E Q: The expression of beclin-1, an autophagic gene, in hepatocellular carcinoma associated with clinical pathological and prognostic significance.BMC Cancer 2014;14:327. 


\section{Cellular Physiology Cell Physiol Biochem 2016;39:13-32 \begin{tabular}{ll|l} 
DOI: 10.1159/000445602 & $\begin{array}{l}\text { O 2016 The Author(s). Published by S. Karger AG, Basel } \\
\text { www.karger.com/cpb }\end{array}$
\end{tabular} \\ Ji et al.: Angiotensin II Enhances Proliferation and Inflammation via AT1/ PKC/NF-кB}

43 Sakurai T, He G, Matsuzawa A, Yu GY, Maeda S, Hardiman G, Karin M: Hepatocyte necrosis induced by oxidative stress and IL-1 alpha release mediate carcinogen-induced compensatory proliferation and liver tumorigenesis. Cancer Cell 2008;14:156-165.

44 Moore RJ, Owens DM, Stamp G, Arnott C, Burke F, East N, Holdsworth H, Turner L, Rollins B, Pasparakis M, Kollias G, Balkwill F: Mice deficient in tumor necrosis factor-alpha are resistant to skin carcinogenesis. Nat Med 1999;5:828-831.

45 Balkwill F: Tumour necrosis factor and cancer. Nat Rev Cancer 2009;9:361-371.

46 Du N, Feng J, Hu LJ, Sun X, Sun HB, Zhao Y, Yang YP, Ren H: Angiotensin II receptor type 1 blockers suppress the cell proliferation effects of angiotensin II in breast cancer cells by inhibiting AT1R signaling. Oncol Rep 2012;27:1893-1903.

47 Wu TT, Hsieh YH, Hsieh YS, Liu JY: Reduction of PKC alpha decreases cell proliferation, migration, and invasion of human malignant hepatocellular carcinoma. J Cell Biochem 2008;103:9-20.

48 Lu HC, Chou FP, Yeh KT, Chang YS, Hsu NC, Chang JG: Expression of protein kinase C family in human hepatocellular carcinoma. Pathol Oncol Res 2010;16:385-391.

49 Guo K, Li Y, Kang X, Sun L, Cui J, Gao D, Liu Y: Role of PKCbeta in hepatocellular carcinoma cells migration and invasion in vitro: a potential therapeutic target. Clin Exp Metastasis 2009;26:189-195.

50 Liang B, Wang X, Zhang N, Yang H, Bai R, Liu M, Bian Y, Xiao C, Yang Z: Angiotensin-(1-7) Attenuates Angiotensin II-Induced ICAM-1, VCAM-1, and MCP-1 Expression via the MAS Receptor Through Suppression of P38 and NF-אB Pathways in HUVECs. Cell Physiol Biochem 2015;35:2472-2482.

51 Qi HP, Wang Y, Zhang QH, Guo J, Li L, Cao YG, Li SZ, Li XL, Shi MM, Xu W, Li BY, Sun HL: Activation of peroxisome proliferator-activated receptor $\gamma$ (PPAR $\gamma$ ) through NF- $\kappa \mathrm{B} / \mathrm{Brg} 1$ and TGF- $\beta 1$ pathways attenuates cardiac remodeling in pressure-overloaded rat hearts. Cell Physiol Biochem 2015;35:899-912.

51 Ning BF, Ding J, Liu J, Yin C, Xu WP, Cong WM, Zhang Q, Chen F, Han T, Deng X, Wang PQ, Jiang CF, Zhang JP, Zhang X, Wang HY, Xie WF: Hepatocyte nuclear factor $4 \alpha$-nuclear factor- $\kappa B$ feedback circuit modulates liver cancer progression. Hepatology 2014;60:1607-1619.

52 Huang JJ, Chu HX, Jiang ZY, Zhang XJ, Sun HP, You QD: Recent advances in the structure-based and ligand-based design of IKK $\beta$ inhibitors as anti-inflammation and anti-cancer agents. Curr Med Chem 2014;21:3893-3917.

53 Wang X, Wang Q, Hu W, Evers BM: Regulation of phorbol ester-mediated TRAF1 induction in human colon cancer cells through a PKC/RAF/ERK/NF-kappaB-dependent pathway. Oncogene 2004;23:1885-1895.

54 Phalitakul S, Okada M, Hara Y, Yamawaki H. Vaspin prevents TNF-alpha-induced intracellular adhesion molecule-1 via inhibiting reactive oxygen species- dependent NF-kappaB and PKCtheta activation in cultured rat vascular smooth muscle cells. Pharmacol Res 2011;64:493-500.

55 Bai X, Wang J, Guo Y, Pan J, Yang Q, Zhang M, Li H, Zhang L, Ma J, Shi F, Shu W, Wang Y, Leng J: Prostaglandin E2 stimulates $\beta 1$-integrin expression in hepatocellular carcinoma through the EP1 receptor/PKC/NF- $\kappa B$ pathway. Sci Rep 2014;4:6538. 